\title{
9. SITE 454: NEAR THE CENTER OF THE MARIANA TROUGH ${ }^{1}$
}

\author{
Shipboard Scientific Party ${ }^{2}$
}

\section{HOLE 454}

Date occupied: 5 April 1978

Date departed: 5 April 1978

Time on hole: 20 hours 54 minutes

Position: $18^{\circ} 00.78^{\prime} \mathrm{N}$; $144^{\circ} 31.92^{\prime} \mathrm{E}$

Water depth (sea level; corrected m, echo-sounding): 3816

Water depth (rig floor; corrected m, echo-sounding): 3826

Bottom felt (m, drill pipe): 3828.5

Penetration (m): 38.5

Number of holes: 1 of 2

Number of cores: 5

Total length of cored section $(\mathrm{m}): 38.5$

Total core recovered $(\mathrm{m}): 22.51$

Core recovery $(\%): 58.4$

Oldest sediment cored:

Depth sub-bottom (m): 38.5

Nature: vitric mud

Age: late Pleistocene

Measured velocity $(\mathrm{km} / \mathrm{s}): 1.52$

Basement:

Depth sub-bottom (m): not attained

Principal results: Site 454 (SP-4E) is located in a small sediment pond in the shallow, central portion of the Mariana Trough. The site is on what should be the youngest crust west of the back-arc axis of spreading where there is enough sediment for us to spud-in. After penetrating 38.5 meters of hemipelagic, biogenic, mainly siliceous sediments, we had to abandon the hole when adverse weather conditions caused the Glomar Challenger to experience rolls up to $13^{\circ}$.

\section{HOLE 454A}

Date occupied: 6 April 1978

Date departed: 9 April 1978

Time on hole: 102 hours 36 minutes (includes time waiting on weather after Hole 454)

\footnotetext{
1 Initial Reports of the Deep Sea Drilling Project, Volume 60.

2 Donald M. Hussong (Co-Chief Scientist), Hawaii Institute of Geophysics, Honolulu, Hawaii; Seiya Uyeda (Co-Chief Scientist), Earthquake Research Institute, University of Tokyo, Tokyo, Japan; René Blanchet, Université de Bretagne Occidentale, Brest, France: Ulrich Bleil, Institut für Geophysik, Ruhr Universitat, Bochum, Federal Republic of Germany; C. Howard Ellis, Marathon Oil Company, Denver Research Center, Littleton, Colorado; Timothy J. G. Francis, Institute of Oceanographic Sciences, Surrey, United Kingdom Patricia Fryer, Hawaii Institute of Geophysics, Honolulu, Hawaii; Ki-lti Horai, Lamont Doherty Geological Observatory, Palisades, New York; Stanley Kling, Marine Life Research Group, Scripps Institution of Oceanography, La Jolla, California (present address: 416 Shore View Lane, Leucadia, California); Arend Meijer, Department of Geosciences, University of Arizona, Tucson, Arizona; Kazuaki Nakamura, Earthquake Research Institute, University of Tokyo, Tokyo, Japan; James H. Natland, Deep Sea Drilling Project, Scripps Institution of Oceanography, La Jolla, California; Gordon H. Packham, Department of Geology and Geophysics, University of Sydney, Sydney, N.S.W. Australia; and Anatoly Sharaskin, Vernadsky Institute of Geochemistry, U.S.S.R. Academy of Sciences, Moscow, U.S.S.R.
}

Position: $18^{\circ} 00.78^{\prime} \mathrm{N} ; 144^{\circ} 31.92^{\prime} \mathrm{E}$

Water depth (sea level; corrected m, echo-sounding): 3816

Water depth (rig floor; corrected $\mathrm{m}$, echo-sounding): 3826

Bottom felt (m, drill pipe): 3929.0

Penetration (m): 171.5

Number of holes: 2 of 2

Number of cores: 16

Total length of cored section (m): 142.5

Total core recovered. $(\mathrm{m}): 40.92$

Core recovery $(\%): 28.7$

Oldest sediment cored:

Depth sub-bottom (m): 145

Nature: bioturbated vitric mudstone

Age: early Pleistocene (0.9-1.6 m.y.)

Measured velocity $(\mathrm{km} / \mathrm{s}): 2.1-2.3$

Basement:

Depth sub-bottom (m): 67

Nature: basalts interbedded with sediments

Velocity range $(\mathrm{km} / \mathrm{s}): 4.2-5.1$

Principal results: Drilling of Hole 454A (SP-4E) was begun without repositioning the ship after being forced to abandon Hole 454 and waiting 20 hours for adverse weather to improve. Total penetration was 171.5 meters with a 41 percent recovery rate. The upper 67 meters were vitric mud and ash with abundant radiolarians and nannofossils, underlain by an approximately 10 -meter-thick sequence of massive pillow basalts composed of at least two cooling units with distinct mineralogies. From 77 to 117 meters, vitric mudstones and tuffs interbedded with apparently thin (less than $50-\mathrm{cm}$ each) pillow basalt flows were encountered. Two massive, generally aphyric, fine-grained basalt flows about 12 and 8 meters thick, separated by 2 meters of sediment, overlie the deepest sediment that was recovered from about 139-149 meters beneath the sea floor. These sediments contained nannofossils indicating an age range of 0.9 to $1.6 \mathrm{~m} . \mathrm{y}$. These determinations overlap an age range of 1.4 to 1.9 m.y. from paleomagnetic analysis. The sediments contain several sedimentary cycles of graded bedding over laminated bedding over bioturbated layers. Below these deepest cored sediments, interbedded spherulitic pillow fragments and microlitic basalts were encountered to the bottom of the hole. The deeper basalts were very fractured and they repeatedly caved in, eventually causing termination of the hole.

The hole was fully logged from the bottom of the partially lifted drill string $(82 \mathrm{~m})$ to the bottom of the partially collapsed hole (about $150 \mathrm{~m}$ below the sea floor). The successful logging permitted reliable reconstruction of the interbedded sequences even though the core recovery through this region was very poor $(<18 \%)$. The large-scale downhole resistivity experiment was successfully completed after the downhole logging.

Downhole heat flow measurements gave a surprisingly low value of $0.06 \mathrm{HFU}$, which may represent the cooling effect of sea water circulating into the basement from the drill hole.

\section{BACKGROUND AND OBJECTIVES}

The general framework of scientific objectives of drilling in the Mariana Trough back-arc basin portion of the South Philippine Sea transect (Fig. 1) has been 


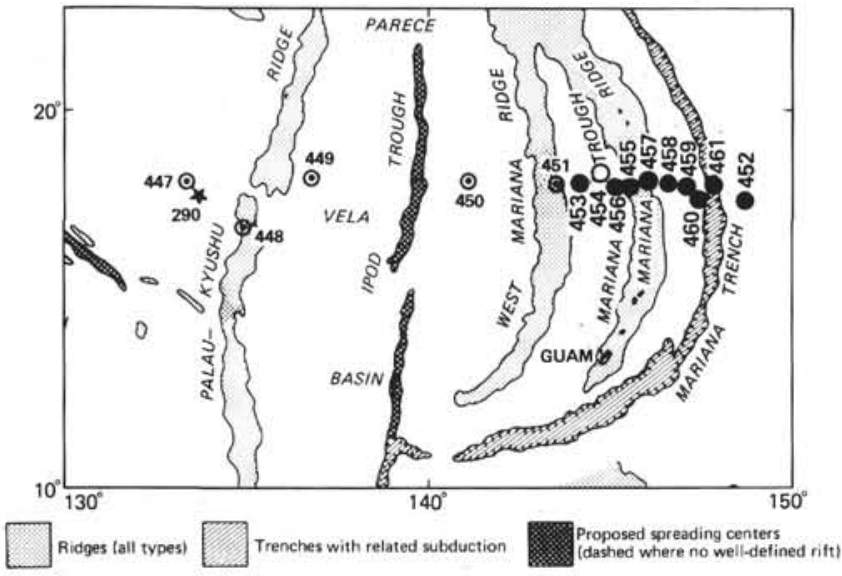

Figure 1. Location of Site $454(\bigcirc)$ in the Mariana Trough, plus other Leg 60 sites (-) and sites from previous legs.

discussed in the Background and Objectives chapter for the Mariana Trough of this volume, so it will not be repeated here.

Holes 454 and 454A, which are at the same location, are in a small sediment pond (Fig. 2) near the center of the Mariana Trough. The pond was designated "Target SP-4E" for site survey and planning purposes. The drilling objective was to acquire samples of very young back-arc basin crust. Thus, the main criterion for the site selection was to identify a sediment pond of adequate dimensions so that we could spud-in the drill string, and as close as possible to the apparent axis of spreading in the Trough. The samples were to be subjected to petrologic study to determine the relationship of rock types in this well-developed young portion of the basin to the rocks found during its earlier opening stages (Sites 453 and 456), on the island-arc (Sites 457 and 458), at mid-ocean ridges, and in other back-arc basins (e.g., Wood et al., this volume; Fryer et al.; this volume).

Spreading rates for the Mariana Trough are variously interpreted to average from $8 \mathrm{~cm} / \mathrm{y}$. (Karig, 1971) to 1.5 $\mathrm{cm} / \mathrm{y}$. (Bibee, 1979). It was therefore important to obtain a reliable age determination at Site 454 , by paleontologic, paleomagnetic, and/or radiometric means, to constrain the estimates of spreading history in the Trough. In conjunction with age dates for Sites 453 and 456 , the site provides control over models of episodic and/or asymmetric spreading in the Trough.

Site 454 permits us to focus on the sedimentation history of young basin crust which is far from the subaerial volcanoes that form the Mariana arc. Sedimentation was influenced only by processes of volcanism and crustal genesis that have occurred during the past one or two million years. During this period the Mariana trencharc-basin system was tectonically configured much as it is now. At the time we drilled Site 454, for example, we expected that the high sedimentation rates observed at Site 453 , which are presumably functions of the close proximity of the young Mariana arc volcanoes and the initial opening phases of the Mariana Trough, would not have occurred at Site 454 . We also expected the igneous rocks at Site 454 to carry the story of any com-

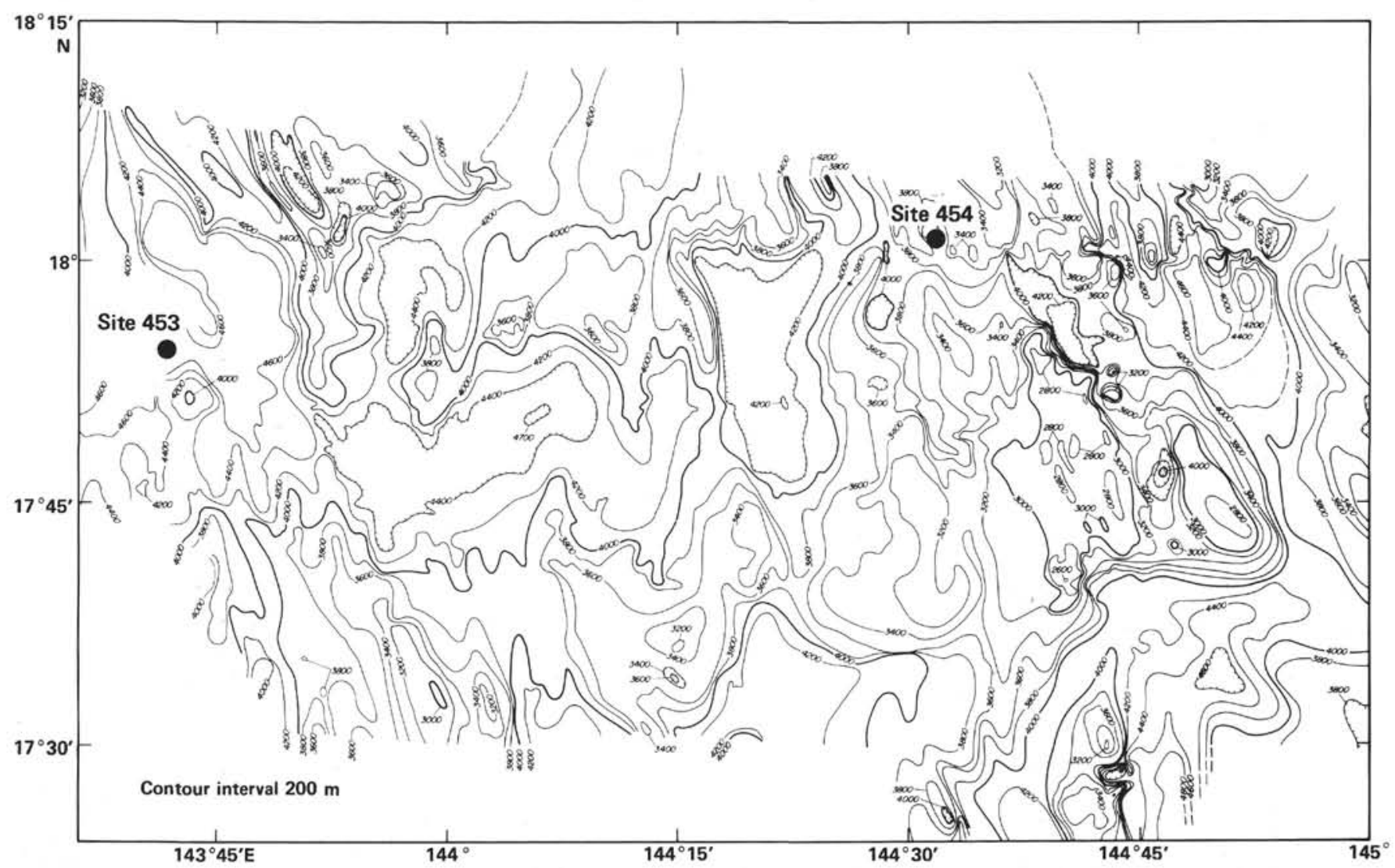

Figure 2. Bathymetry of a portion of the Mariana Trough near Site 454 . Contour interval is 200 corrected meters. Site 453 is also shown. 
positional change which has occurred in the back-arc basin crust, as its potential magma source becomes geographically more removed from the island arc volcanism. The older portion of the Mariana Trough exhibits more chaotic bathymetry than the younger crust, which (at least in our transit area along $17^{\circ} 15-18^{\circ} 15^{\prime} \mathrm{N}$ ) appears symmetric around a graben (Fig. 3 ). If the contrast between the older lack of symmetry and the younger symmetry is a function of the mode of back-arc spreading, are these differences reflected in the composition of the upper crustal tocks?

Site 454 is located in a region of the Mariana Trough that is relatively shallow (averaging about $3700 \mathrm{~m}$, Fig. 2). Except for a few tiny sediment ponds, which are smaller than the one we drilled in this axial portion of the Trough, the Trough is devoid of sediments. Largely based on this consideration, the axial-high region was considered the possible axis of spreading in the Trough by some workers. Seismic studies conducted near survey area SP-4E by the Hawaii Institute of Geophysics as part of the IPOD site survey effort show that seismic energy propagation and crustal structure beneath SP-4E are normal when compared with the rest of the Trough. High attenuation of energy and abnormal crustal structure are generally found at a crustal spreading center. Natural seismicity levels, magnetic anomaly trends, and bathymetric trends indicated by the site surveys (Fryer and Hussong, this volume) have since led us to suspect that the axis of spreading may more likely be in the graben-like deep portion of the Mariana Trough approximately $28 \mathrm{~km}$ east of Site 454 .

Site 454 is about $130 \mathrm{~km}$ west of the active volcanic arc of the Mariana Island, and $100 \mathrm{~km}$ east of the eastern edge of the West Mariana Ridge.

\section{OPERATIONS}

After a short post-drilling survey of Site 453 , the Challenger sailed for target site SP-4E. The standard geophysical profiling system $(3.5-\mathrm{kHz}$ and $12-\mathrm{kHz}$ bathymetry, 120-cu. in. air gun with single hydrophone array, and magnetometer) were used for the transit and surveying.

The small sediment pond that had been chosen for SP4-E prior to Leg 60 had been missed on the earlier Challenger transect (Fig. 3) of the area between Holes 452 and 453 (Hussong, this volume), but this time we were able to locate it on our first pass (Fig. 4) and dropped a $16.0-\mathrm{kHz}$ double-life beacon at 1940 local on 4 April, 1978. A short survey of the pond to delineate its shape, the position of the beacon, and the configuration of a strong seismic reflection occurring above the acoustic basement and at only 85 milliseconds below the sea floor, was completed by 2212 on 4 April (for results see Geophysics section, this chapter).

The strong shallow reflector was interpreted potentially as either interlayered basalt and sediments or an igneous breccia zone as encountered at Hole 453, so a short bottom-hole assembly consisting of the core barrel, only five drill collars, and one bumper sub, for a total length of 83 meters, was assembled. This con- figuration is less desirable for maximum bottom penetration because the single bumper sub allows less flexibility in drilling procedures, particularly by permitting application of less weight to the bit. It is prudent, however, to have as much as possible of the relatively fragile bottom-hole assembly buried in the sediment before trying to penetrate lithified sediments or crystalline rock. The thin sediment at Site 454 dictated use of the short bottom-hole assembly. A F93CK bit was selected.

The pipe string was rur and bottom felt and cored at a pipe string length of 3828.5 meters at 0720 on 5 April 1978. The coring summary is given in Table 1 .

After acquiring four sediment cores, the Tokyo T-probe was run to the bottom of the hole at 29 meters below the sea floor. The measurement was unsuccessful due to electronic problems with the instrument.

After Core 5, which penetrated to $\mathbf{3 8 . 5}$ meters, the hole was abandoned since worsening weather conditions were causing the ship to roll regularly 5-6 degrees, with an occasional roll as great as 13 degrees. This motion was especially undesirable with a portion of the bottomhole assembly still above bottom.

The weather was not particularly severe $(\sim 25$-knot winds), but the wind and seas were coming from the east while a long swell came from the north. The ship had to point into the wind, thus orienting itself in the trough relative to the long swell, which caused the excessive roll.

We pulled out of the hole at 1636 on 5 April. Seven pipe stands were pulled to get well off the bottom, and then one stand per hour was pulled to prevent wear on any one section while in contact with the ship.

By the following morning (6 April), conditions had eased and drilling was resumed. Hole 454A was spudded at 1218 local time; this hole is charted at the same position as Hole 454. The coring summary is continued in Table 1. The first 9.5 meters was cored because there was no recovery of this interval from Hole 454. Subsequently, we washed down to 38.5 meters, because it did not seem worthwhile to duplicate the soupy disturbed material obtained from this interval in Site 454. The heave compensator was used for Cores 5-14 because of poor weather and the short bottom assembly.

Basalt was first encountered in Core 4,CC $(\sim 67 \mathrm{~m})$, matching the 85 -millisecond reflector $(67 \mathrm{~m}$ at $1.57 \mathrm{~km}$ / s) observed in the surface seismic records. Interbedded basalts and sediments were subsequently cored to a total penetration of 171.5 meters.

Recovery dropped severely toward the bottom of the hole as torquing increased (Fig. 5) and pump pressure had to be raised. The string became stuck during Core 14. When the string was finally freed, 30 barrels of mud was spotted to try to clear the hole. Nevertheless, increasing torquing and sticking in the hole, caused by apparent collapse of the lower portions of the hole, finally forced us to pull up at 2335 on 7 April. A final core inner barrel, which would have been for Core 17, was retrieved with a sample from an unknown depth (the hole had filled in to well above the top of the Core 16 interval by the time the string was lowered for the last time before pulling out). 


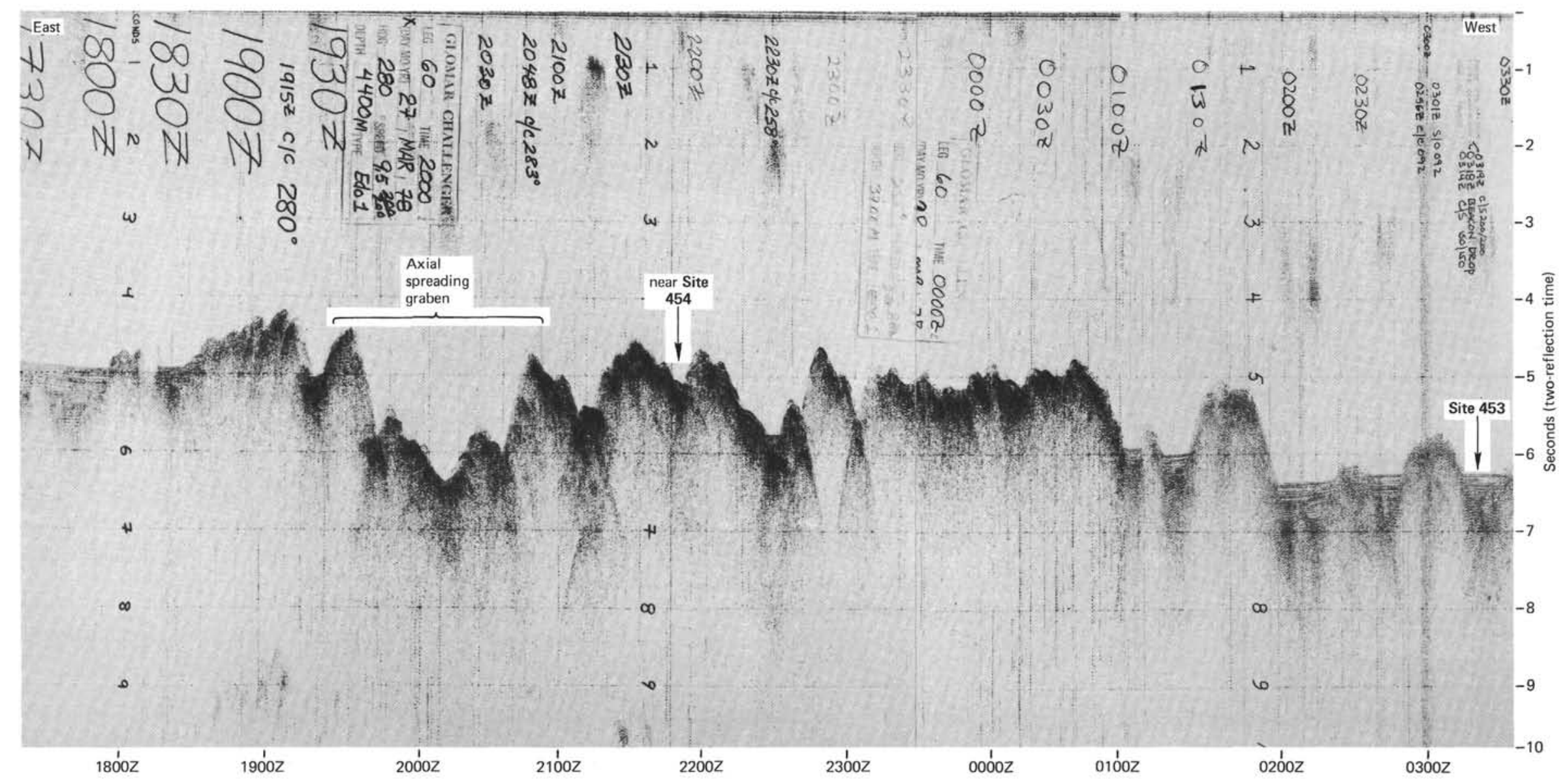

Figure 3. Glomar Challenger profiler record over Site 454 and approaching Site 453. Note tilting of fault blocks away from the graben. 


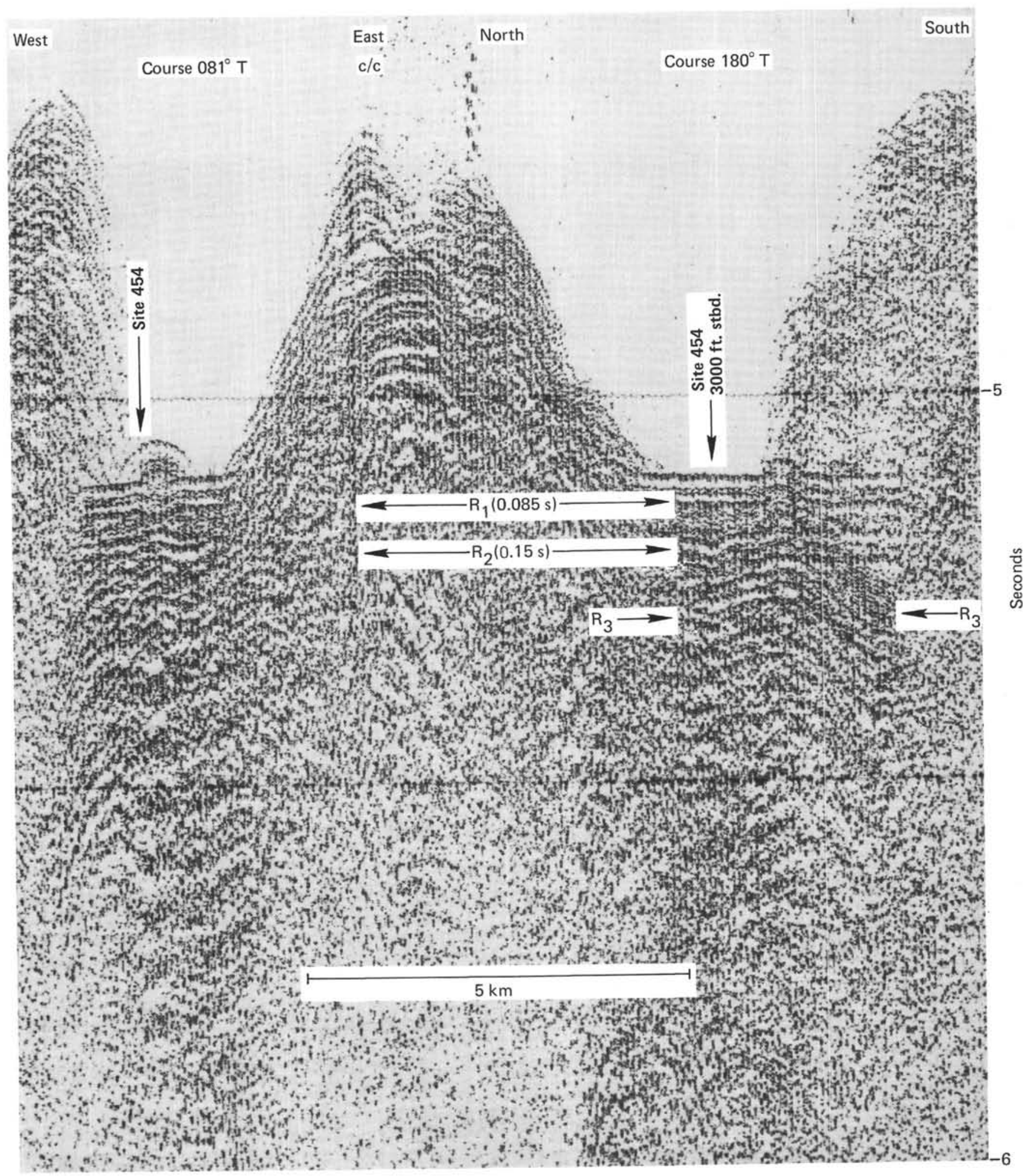

Figure 4. Challenger air-gun seismic reflection record during the maneuvering over the sediment pond at Site 454 . Note the pervasive flat subbottom reflection $\left(R_{1}\right.$ and $\left.R_{2}\right)$ and the even deeper, more irregular reflector $\left(R_{3}\right)$. 
Table 1. Coring summary, Site 454.

\begin{tabular}{|c|c|c|c|c|c|c|c|}
\hline Core & $\begin{array}{l}\text { Date } \\
\text { (April } \\
1978)\end{array}$ & Time & $\begin{array}{l}\text { Depth from } \\
\text { Drill Floor } \\
\text { (m) }\end{array}$ & $\begin{array}{l}\text { Depth below } \\
\text { Sea Floor } \\
\text { (m) }\end{array}$ & $\begin{array}{l}\text { Length } \\
\text { Cored } \\
\text { (m) }\end{array}$ & $\begin{array}{l}\text { Length } \\
\text { Recovered } \\
\text { (m) }\end{array}$ & $\begin{array}{c}\text { Recovery } \\
(\%)\end{array}$ \\
\hline \multicolumn{8}{|c|}{ Hole 454} \\
\hline 1 & 5 & 0815 & $3828.5-3829.0$ & $0.0-0.5$ & 0.5 & 0.02 & 4.0 \\
\hline 2 & 5 & 0933 & $3829.0-3838.5$ & $0.5-10.0$ & 9.5 & 0 & - \\
\hline 3 & 5 & 1054 & $3838.5-3848.0$ & $10.0-19.5$ & 9.5 & 5.96 & 62.7 \\
\hline 4 & 5 & 1204 & $3848.0-3857.5$ & $19.5-29.0$ & 9.5 & 8.45 & 88.9 \\
\hline 5 & 5 & 1524 & $3857.5-3867.0$ & $29.0-38.5$ & 9.5 & 8.08 & 85.0 \\
\hline Total & & & & & 38.5 & 22.51 & 58.12 \\
\hline \multicolumn{8}{|c|}{ Hole 454A } \\
\hline 1 & 6 & 1305 & $3829.0-3838.5$ & $0.5-10.0$ & 9.5 & 8.22 & 86.5 \\
\hline 2 & 6 & 1601 & $3867.0-3876.5$ & $38.5-48.0$ & 9.5 & 4.70 & 49.4 \\
\hline 3 & 6 & 1713 & $3876.5-3886.0$ & $48.0-57.5$ & 9.5 & 4.40 & 46.3 \\
\hline 4 & 6 & 1949 & $3886.0-3895.5$ & $57.5-67.0$ & 9.5 & 3.65 & 38.4 \\
\hline 5 & 6 & 2306 & $3895.5-3905.0$ & $67.0-76.5$ & 9.5 & 4.0 & 42.0 \\
\hline 6 & 7 & 0209 & $3905.0-3914.5$ & $76.5-86.0$ & 9.5 & 3.11 & 32.7 \\
\hline 7 & 7 & 0347 & $3914.5-3923.5$ & $86.0-95.0$ & 9.0 & 0 & 0 \\
\hline 8 & 7 & 0500 & $3923.5-3932.5$ & $95.0-104,0$ & 9.0 & 2.21 & 24.6 \\
\hline 9 & 7 & 0614 & $3932.5-3941.5$ & $104.0-113.0$ & 9.0 & 0.10 & 1.1 \\
\hline 10 & 7 & 0750 & $3941.5-3950.5$ & $113.0-122.0$ & 9.0 & 0.65 & 7.2 \\
\hline 11 & 7 & 0948 & $3950.5-3959.5$ & $122.0-131.0$ & 9.0 & 4.79 & 53.2 \\
\hline 12 & 7 & 1115 & $3959.5-3968.5$ & $131.0-140.0$ & 9.0 & 2.15 & 23.9 \\
\hline 13 & 7 & 1239 & $3968.5-3977.5$ & $140.0-149.0$ & 9.0 & 1.33 & 14.8 \\
\hline 14 & 7 & 1540 & $3977.5-3986.5$ & $149.0-158.0$ & 9.0 & 0.50 & 5.5 \\
\hline 15 & 7 & 1853 & $3986.5-3990.5$ & $158.0-162.0$ & 4.0 & 0.11 & 2.7 \\
\hline 16 & 7 & 2135 & $3990.5-4000.0$ & $162.0-171.5$ & 9.5 & 1.0 & 10.5 \\
\hline Total & & & & & 142.5 & 40.92 & 28.7 \\
\hline
\end{tabular}
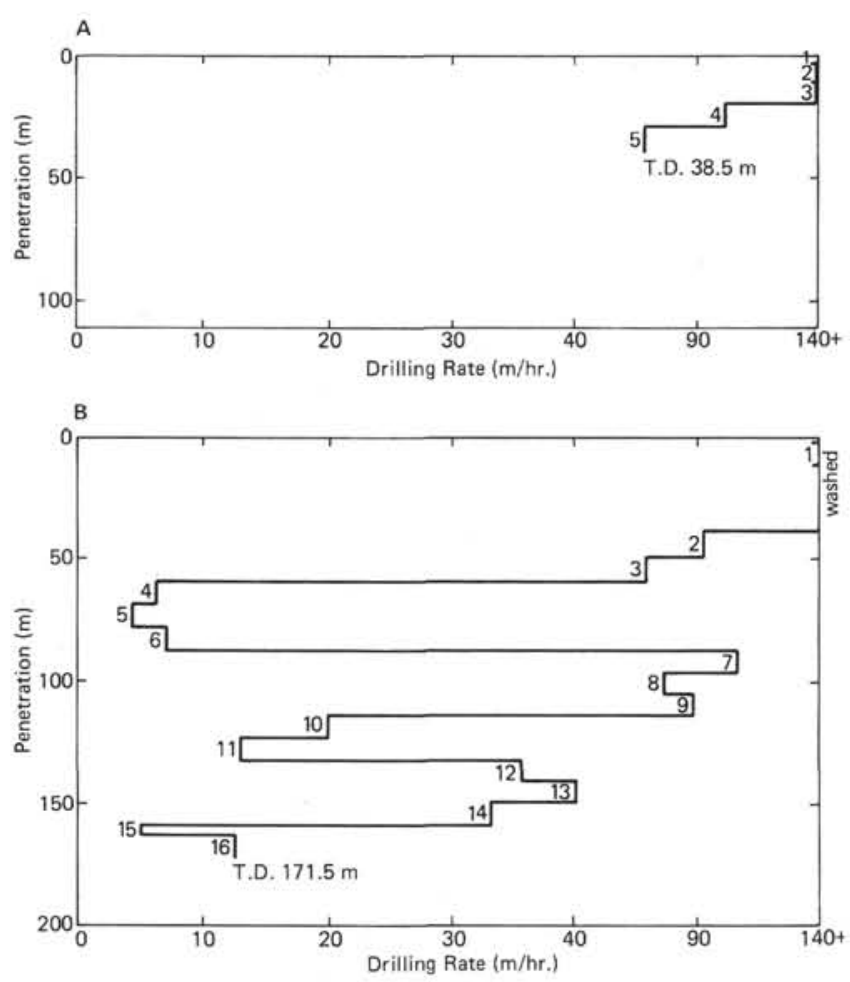

Figure 5. Drilling rates per core, Holes 454 (A) and 454A (B). T.D. = total depth. Core numbers are shown on the figure.

Prior to releasing the bit, the Tokyo T-probe was run to a depth of 3968.5 meters, and an apparently good measurement was obtained.

The bit was then released and the full set of GearhartOwen downhole logs were run. This logging included temperature, gamma-density, caliper, sonic velocity, gamma-neutron, gamma-induction, $\mathrm{XY}$ caliper, and finally a repeat of the temperature $\log$, in that order. The complete logging program was accomplished from the bottom of the drill string (approx. $3911.5 \mathrm{~m}$ ) to the top of where the hole had filled in (approximately 3977 $\mathrm{m})$. Useful logging data were actually obtained considerably below the bottom of the drill string. This was a short interval for such complete logging, but because we had interbedded sediments and basalts, fairly poor recovery $(29 \%)$, and it was our first chance to log, we decided to make as many measurements as possible. The Gearhart-Owen logging was done from 0700 on 8 April to 0630 on 9 April.

The downhole resistivity experiment was then run from 0815 to 1618 on 9 April, also with apparently good results (Francis, this volume). At the completion of this work the drill string was brought aboard.

The Challenger departed for the next survey target (SP-4D) at 2315 on 9 April 1978.

\section{LITHOLOGY OF SEDIMENTS}

At Site 454, two holes were drilled (Holes 454 and $454 \mathrm{~A}$ ), penetrating 38.5 meters of sediment in Hole 454 and 133 meters of deeper sediments and basalts in Hole 454A. As the holes were very close and overlapping, a total penetration of 171.5 meters was obtained. Basalt was first encountered at a sub-bottom depth of about 67 meters (Core 454A-4).

The drilled sequence has been divided into two units (Fig. 6). Unit I is the sedimentary sequence overlying the basalts and Unit II contains interbedded sediments and basalts.

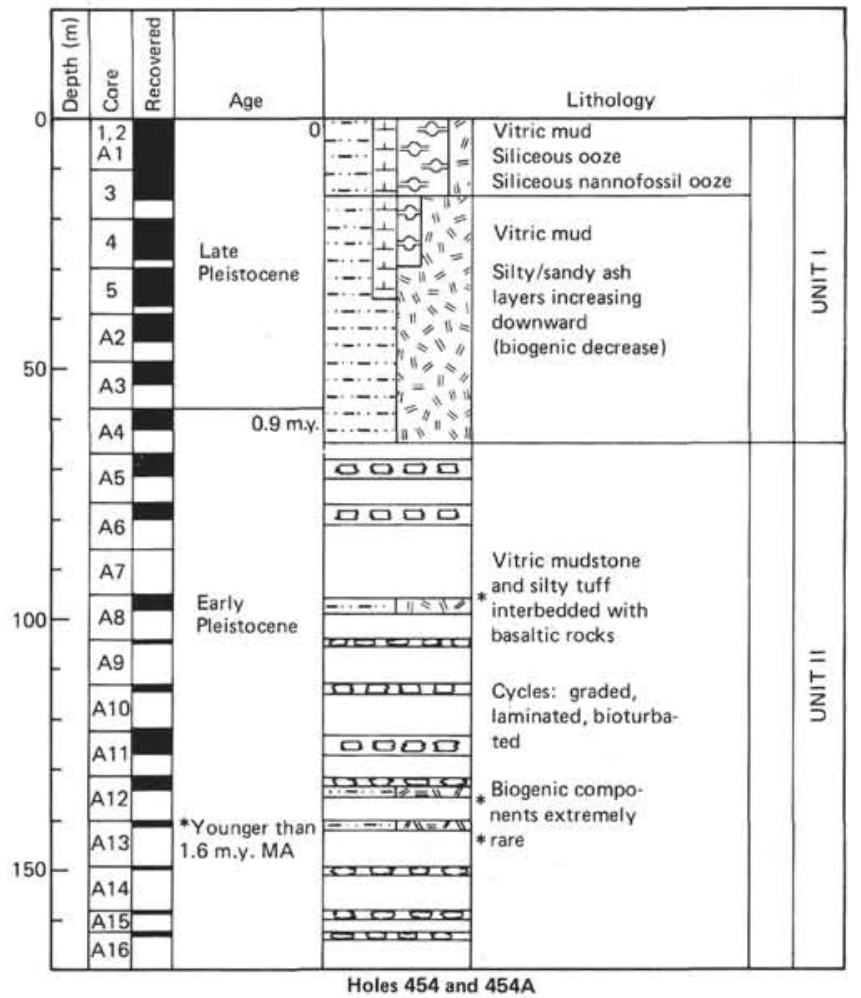

Figure 6. Lithologic summary, Site 454. Lithologies for Unit II are given only for recovered intervals. See Figure 8 for reconstruction based on logging data. Symbols are as in introductory chapter Explanatory Notes. 
Unit I: 67 Meters Thick, Late Pleistocene to Uppermost Early Pleistocene

It is represented by Cores SP-4F (piston core from the Hawaii Institute of Geophysics site survey), 454$1(\mathrm{CC})$ through 5 and $454 \mathrm{~A}-1$ through 4.

Basically, Unit I consists of hemipelagic sediments (mud and vitric mud with volcanic ash) and biogenic sediments (siliceous ooze, siliceous nannofossil ooze, nannofossil ooze).

Mud and volcanic ash are present all through the unit (clayey, silty, and sandy vitric ash). Most of those sediments contain over 10 per cent of volcanogenic components. Ash layers increase downward between 15 and 57 meters; but sandy ash layers are mainly present above 31.7 meters. The color is generally greenish gray to olive-gray. Silty and sandy ash layers are the darker lithologies.

Sediments rich in biogenic components are lighter in color (dusky to dark yellowish brown). Among the biogenic sediments, siliceous ooze (with radiolarians, diatoms, and sponge spicules) and siliceous nannofossil marly ooze are dominant. Nannofossil-foraminifer marly ooze is also present. Biogenic sediments are well developed ( $50 \%$ and over) between 0 and 15 meters; they decrease progressively downward.

Some layers rich in unidentified micronodules were also encountered (Core SP-4E, Section 454-4-4).

\section{Unit II: 67 to 171.5 Meters, Early Pleistocene}

Unit II consists of alternating sediment layers and basalts (massive lavas and pillow lavas). The sediments probably represent two continuous layers interbedded with basalts. They are observed in three cores-Cores 8 (Sections 1 and 2), 12, and 13. Lithologically, they are mostly hemipelagic sediments (vitric mudstone and claystone) with clayey to silty vitric tuff. Biogenic components, mainly nannofossils, become extremely restricted. A few per cent is usual, but biogenic components rarely exceed 10 per cent.

In this unit, we find cyclic sedimentary structures similar to those observed in cores at Site 453 . They consist of basal-graded layers, intermediate, thinly laminated layers, and upper bioturbated layers. Each cycle is at least $10-20 \mathrm{~cm}$ thick (some parts could have been lost during coring). Upper bioturbated layers (vitric mudstones and claystones) are thicker than the coarser graded and laminated ones. In Core 8 are several burrows filled with fecal pellets. Dendrites (Mn?) occur in some bedding planes (Core 13).

In Core 13 (Section $1,70 \mathrm{~cm}$ ) a rather abrupt change in color occurs from moderate to dark greenish gray above to light olive-gray to light olive-brown below. In smear slides, the upper darker part is higher in clay content $(\sim 90 \%)$ and lower in volcanic ash $(10-13 \%)$, while the lower, lighter colored part is higher in ash $(\sim 40 \%)$, silt $(\sim 40 \%)$, and unidentified micronodule $(\sim 20 \%)$ content.

\section{BIOSTRATIGRAPHY}

\section{Summary}

A Quaternary section penetrated at Site 454 can be dated on the basis of calcareous nannofossils through the entire sequence and with radiolarians in the upper part. Except for Core 1 in Hole 454A, which duplicates the interval penetrated by Core 1 in Hole 454, cores in Hole 454A continue below the bottom samples in Hole 454. In the oldest sediment interbedded with basalts at the bottom of Hole 454A, the Gephyrocapsa caribbeanica nannofossil subzone can be recognized, indicating an age range of 0.9 to $1.6 \mathrm{~m} . \mathrm{y}$.

Only impoverished undifferentiated Quaternary foraminiferal assemblages were recovered from Holes 454 and $454 \mathrm{~A}$.

\section{Nannofossils}

The Holocene and part of the late Pleistocene were penetrated in Hole 454. A complete section of late Pleistocene and much of the early Pleistocene were encountered in Hole 454A. All of the Holocene and Pleistocene nannofossil zones and subzones, except the lowest Emiliania annula Subzone, can be recognized. Each of the sedimentary units recovered from between basaltic layers contains calcareous nannofossil assemblages with age-diagnostic species. All of the zones observed in samples from these two holes can be defined by the presence of the primary zone defining species.

In Hole 454, the Holocene Emiliania huxleyi Zone can be identified in Sample 1,CC. No sediments were recovered in Core 2. Cores 3 through 5 can be assigned to the late Pleistocene Emiliania ovata Subzone of the Gephyrocapsa oceanica Zone.

Section 1 of Core 1 in Hole 454A contains nannofossils indicative of the late Pleistocene Ceratolithus cristatus Subzone of the Gephyrocapsa oceanica Zone. This subzone was not observed in samples from Hole 454 , presumably because of the lack of recovery in Core 2 from that hole.

The late Pleistocene Emiliania ovata Subzone of the Gephyrocapsa oceanica Zone can be recognized in Samples 454A-1-2, 90-91 cm through 454A-3,CC.

The early Pleistocene Gephyrocapsa caribbeanica Subzone of the Crenalithus doronicoides Zone can be recognized in Samples 454A-4-2, 82-83 cm through 454A$13-1,132-133 \mathrm{~cm}$. Samples from 454A-8,CC through 454A-13-1, 132-133 cm represent fossiliferous sedimentary occurrences between basaltic layers.

According to the geochronologic time scale for nannofossil zones presented by Bukry (1975), the lowest fossiliferous sediments penetrated at Site 454 can be no younger than 0.9 m.y. and no older than $1.6 \mathrm{~m} . \mathrm{y}$.

\section{Radiolarians}

Well-preserved radiolarians are generally abundant in the upper Quaternary cores of Holes 454 (Cores 1-5) and $454 \mathrm{~A}$ (Cores 1-4). No radiolarians were seen in older sediment. 
Species upon which Nigrini's (1971) Quaternary zonation is based are generally very rare, even in the richest radiolarian assemblages. The latest zone, Buccinosphaera invaginata, can be identified only in the small sample recovered from Core 1 of Hole 454. The Collosphaera tuberosa Zone is recognizable in Core 3 of Hole 454 and in Core 1 of Hole 454A. Only one deeper sample (Sample 454-4,CC) can be assigned with confidence to the Amphirhopalum ypsilon Zone.

\section{SEDIMENT ACCUMULATION RATES}

The sediment accumulation curve (Fig. 7) has been calculated in kilograms of water-free sediment per square centimeter. The calculation was done in the same way as for Site 453, except that averaging was not necessary and the density log was used to determine the proportion of sediment interbedded with the basalt in Unit II. The total sediment accumulated at the site in the drilled section was $7.1 \mathrm{~kg} / \mathrm{cm}^{2}$, accumulated from 0.9 to 1.6 m.y. B.P.

Because of the short duration of sedimentation, only a few boundaries could be determined. The results are as follows (the rate for Segment 3 is for the sediment only):

\begin{tabular}{lcc}
\hline \multicolumn{1}{c}{ Interval } & $\begin{array}{c}\text { Depth below } \\
\text { Seafloor }(\mathrm{m})\end{array}$ & $\begin{array}{c}\text { Accumulation Rate } \\
\left(\mathrm{kg} / \mathrm{cm}^{2} / \mathrm{m} . \mathrm{y} .\right)\end{array}$ \\
\hline 1) $\begin{array}{l}\text { Holocene and latest } \\
\text { Pleistocene } \\
(0-0.3 \text { m.y. })\end{array}$ & $0-2.2$ & 0.5 \\
2) $\begin{array}{l}\text { Late Pleistocene } \\
(0.3-0.9 \text { m.y. }\end{array}$ & $2.2-56.6$ & 6.3 \\
3) $\begin{array}{l}\text { Early Pleistocene } \\
(0.9->1.6 \text { m.y. })\end{array}$ & $56.5-141.3$ & $>4.8$ \\
\hline
\end{tabular}

The accumulation within Segment 1 is substantially lower than within Segment 2. The organic content of the upper part of Segment 2 is similar to that in Segment 1, but it decreases at about 17 meters below the sea floor. It is possible that the lower rate of sedimentation of Segment 1 commenced in the later part of the time of deposition of Segment 2 and is due to a decrease of volcanic activity in the arc in the past $0.3 \mathrm{~m} . \mathrm{y}$.

Segment 3 is entirely within the nannofossil subzone of Gephyrocapsa caribbeanica and commences 10.4 meters above the top of the interbedded basalts and sediment of Unit II. The accumulation rate is probably considerably greater than the calculated minimum of $4.8 \mathrm{~kg} / \mathrm{cm}^{2} / \mathrm{m}$.y. The high rate of deposition may be partly the result of sediment being contributed from local sources as well as the active arc.

\section{LITHOLOGIC SYNTHESIS}

Site 454 is located in the central Mariana Trough, on the western limb of the central high-relief zone $28 \mathrm{~km}$ west of the suspected spreading axis. Seismic profiles show that the site is on the western side of a small sediment pond, the surface of which slopes gently to the west and even more gently to the south. The east and west flanking ridges are steep, with the western being the steeper.

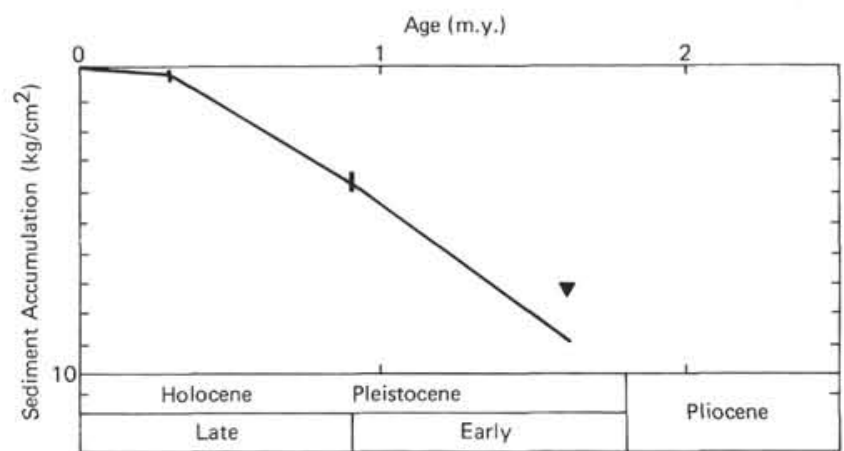

Figure 7. Sediment accumulation $\left(\mathrm{kg} / \mathrm{cm}^{2}\right)$ versus age, Site 454.1 is error bar for depth of zone boundary, $\boldsymbol{\nabla}$ is upper limit for depth of zone boundary.

Only Pleistocene fossil assemblages are recorded in the drilled succession. Sediment at Site 454 are divided into two units, a hemipelagic mudstone associated with abundant but upward decreasing volcanogenic detritus (Unit I) overlying at least two layers (Core 8 and Cores 12 and 13) of hemipelagic sediments interbedded with basalts (Unit II).

In the sediment of Unit II, biogenic components (mainly calcareous nannofossils) are rare, but they contain age-diagnostic forms. Several sedimentary cycles are developed with, from the bottom to top, graded bedding, laminated bedding, and bioturbated layers. Sediment deformation is minor, even next to basalts. Undisturbed horizontal fine lamination is common, occurring in the core samples nearest to underlying basalt (e.g., the lowest sediments above basalts in Section 8-2, at $100 \mathrm{~cm}$, and Section 13-1, at $134 \mathrm{~cm}$ ). Only a single normal fault with $1.5 \mathrm{~mm}$ of displacement was observed in the top sample of the upper sediment layer interbedded with basalts (Section 8-1, 90-95 cm).

We infer the interlayered basalts to be interbedded pillows and flows, since we recovered no baked intrusive contacts, and the level of sediment disturbance was minor.

Comparison of the downhole Gearhart-Owen density logging with wet-bulk density data between Cores 8 and 13 allows the lithologic column to be constructed (Fig. 8) with the following features:

1) Vitric mudstone samples in Cores 12 and 13 make up a single, nearly continuous layer that may possibly include a few basalt fragments (isolated pillows?).

2) An additional 50-cm-thick sediment layer occurs between basalts in the lowest part of Core 11. This layer can be recognized on the logs, but no samples were recovered in the core.

3) Cores 8,9 and the upper two-thirds of Core 10 contain sediments with basalts (pillows?) no thicker than $50-\mathrm{cm}$, the limit of resolution of the density logging tool. A few basalt fragments were recovered in these cores. In this interval, sediment densities obtained by logging range between 1.55 and 1.85 ; by laboratory measurement they give 1.56 for vitric tuff and 2.21 for basalt.

The occurrence of basalts interbedded with turbidite sediments at Site 454 indicates that a basin existed at the site when the last flows of Layer 2 were extruded. While 


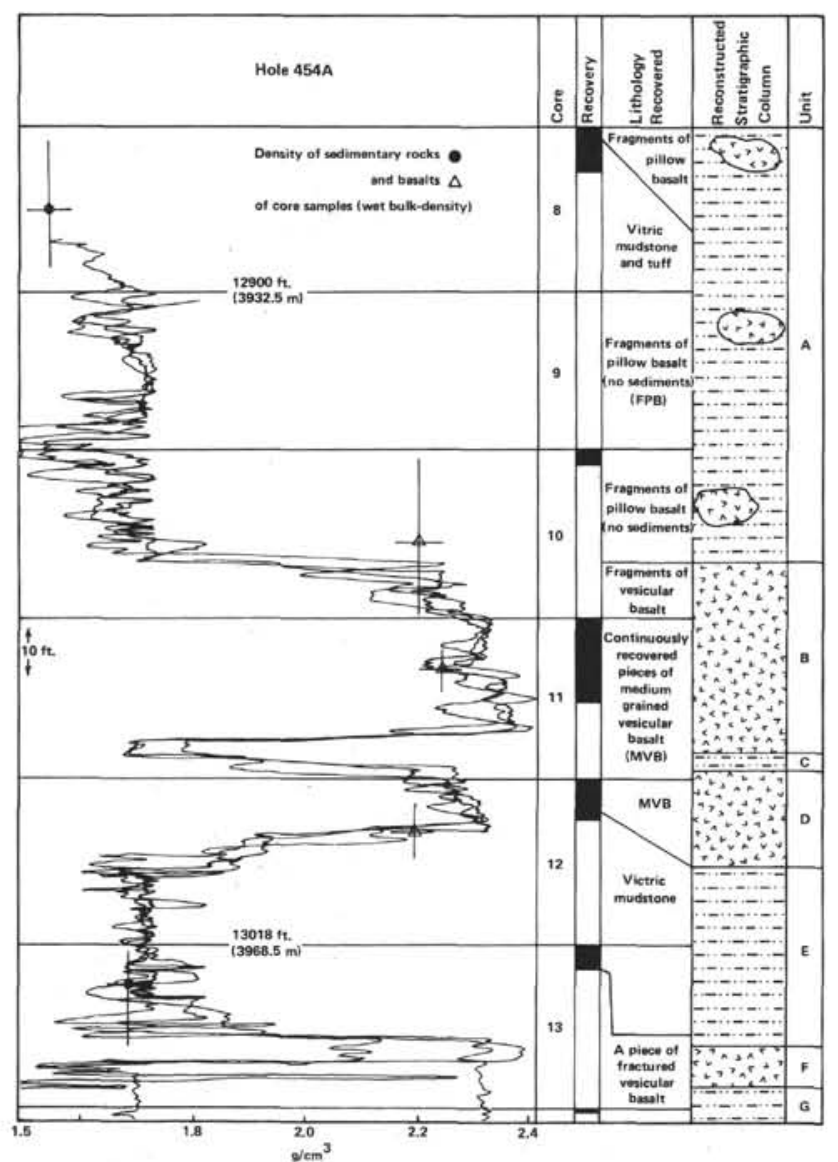

Figure 8. Comparison of three density logs (overlapped) obtained in Hole $454 \mathrm{~A}$ showing the inferred relationship to interbedded massive basalts, pillowed basalts, and sediments. Cores, recovery, and the shipboard classification of lithologic units are also indicated. After shore-based investigation, the lithologic units were revised as in Figure 10.

no data exist on the interbedding of sediments in the basalts on the adjacent ridges, we feel that the ridges probably originated before the conclusion of volcanic activity and therefore may lack interbedded turbidites.

\section{GEOCHEMISTRY}

Two samples were taken for pore water chemistry, one each from Holes 454 and 454A. The data are presented in Gieskes and Johnson (this volume). The samples are virtually identical and differ only slightly from sea water; they resemble near-mudline samples from Site 452.

\section{IGNEOUS AND METAMORPHIC ROCKS}

\section{Lithology and Downhole Chemical Variations}

At Site 454,20 meters of aphyric to sparesly phyric basalt in both massive units and pillow sequences, interspersed with layers of pumice and sedimentary material, was recovered in Cores 4 through 16 . Total basalt penetration was about 104.5 meters including interbedded sediments. The stratigraphy of the basalts and sediment layers is shown in Figure 9. The lithology of the uppermost and lowest portions of the section
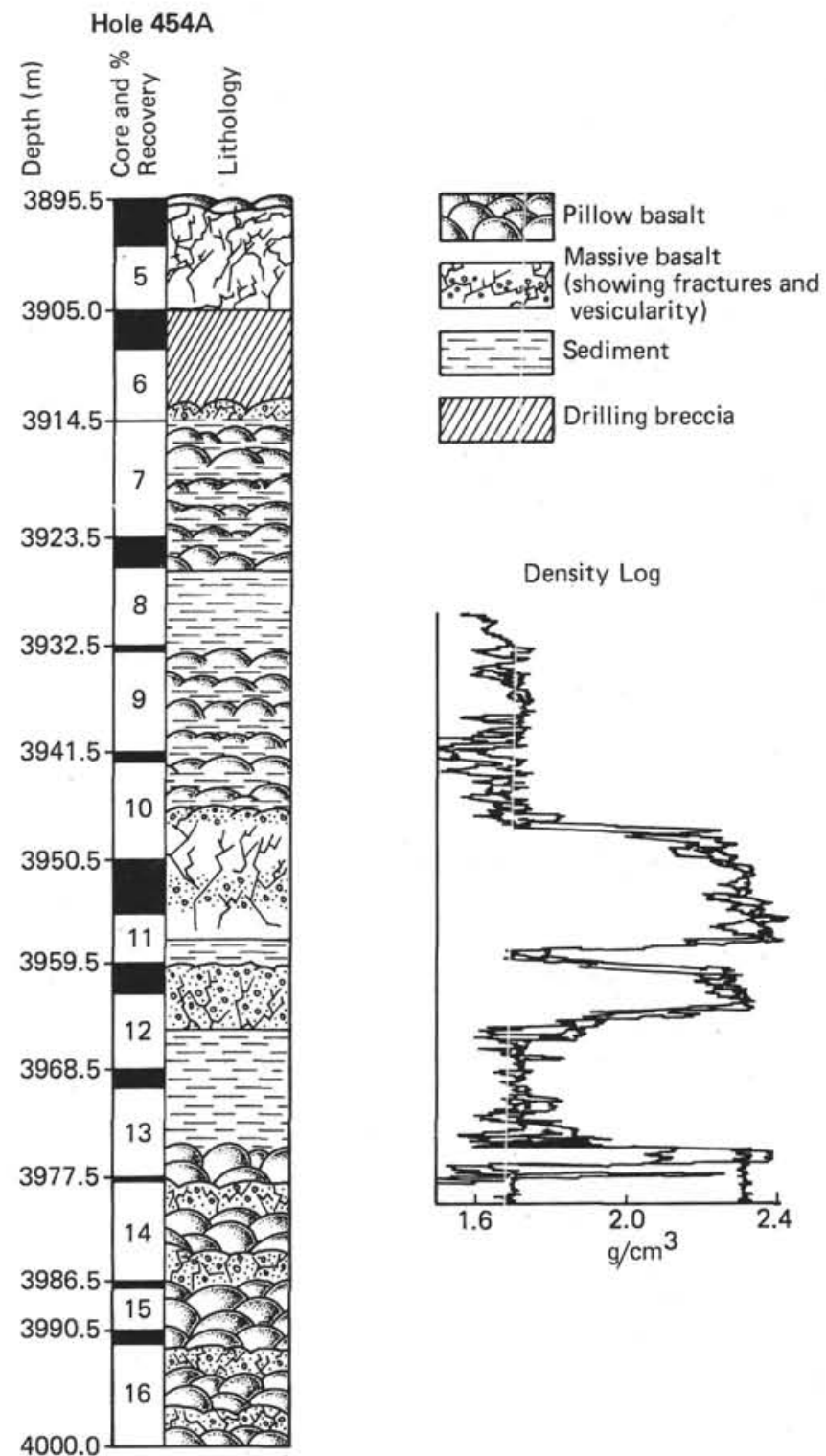

Figure 9. Complete column for the intercalated basalt flow and sediment layer showing depth below the sea surface, core recovery, and lithology of the basalts.

(Cores 4 through 7 and 14 through 16, respectively) was reconstructed based on the assumption that the proportion of material recovered is representative of the true proportions of materials in the intervals cored. From the interval represented by Cores 8 through 13 , the lithology has been reconstructed using the logging results as a guide to the thickness and relative proportions of layers present. We subdivided the basalts into five units on the basis of petrographic and lithologic characteristics (Fig. 10). These will be described in more detail. The first three are similar in composition and are grouped together as a single chemical type, whereas Units 4 and 5 form distinct chemical types (Fig. 11).

The first petrographic unit consists of massive aphyric basalts which probably comprise two cooling units. The upper cooling units appear to be overlain by pillow basalts of similar compositions. A few small glassy pillow fragments interspersed with sediments 
were recovered in the core catcher sample of Core 4 . The upper meter or so of Core 5 is distinctly finegrained, moderately altered basalt which becomes coarser and fresher downward. At the base of Section 5-3, the rocks show microdolerite textures. Fracturing is widespread, and fracture surfaces and veins are coated or filled with carbonate (aragonite, as identified in thin sections and occurring on fracture surfaces, Fig. 12), some chlorite, and in one instance, a botryoidal green coating, probably of green smectite. Aragonite-filled amygdules occur in the middle of Core 5. At the top of Section 5-4, the average grain size decreases perceptibly. In thin sections, the proportion of very fine grained spherulitic patches increase and the typical size of titanomagnetites in these patches decreases. This suggests the base of the cooling unit is close to this depth. However, it was not recovered. Instead, the next several fragments recovered are distinctly coarser grained, less vesicular, and rich in olivine. This suggests a second cooling unit, although neither its top nor bottom was recovered.

Underlying the massive basalt in Core 6, is a graded drilling breccia varying from clay-sized to pebble-sized fragments of pumice, volcanic glass, and coarse-grained basalt. This material is described more fully in the section on sediment lithology. Fragments of mediumgrained, olivine-poor basalt were recovered in the lower part of Core 6 and are indicated as basaltic Unit 2 in Figure 10.

Below the massive basalt is a zone of interbedded sediment and pillow basalt (Cores 7,8,9, and the upper part of Core 10). The basalts in this zone are shown as basaltic Unit 3 of Figure 10. The density distribution as revealed by logging in this interval (see Fig. 8) precludes the presence of thick (larger than $0.5-\mathrm{m}$ ) pillow basalt

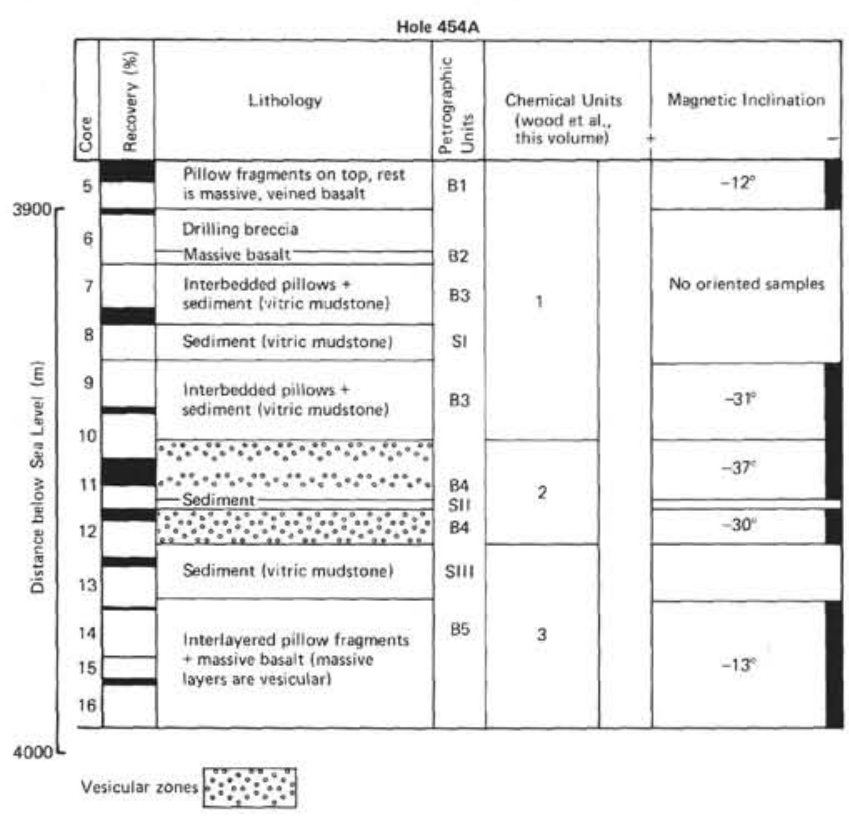

Figure 10. Summary of lithologic units and variation with depth in hole of percentage recovery, lithology, composition, and magnetic inclination. layers interspersed with sediment. The pillow fragments recovered are fresh and display spherulitic textures adjacent to glassy rinds. Olivine appears to be fairly abundant in these rocks, but cannot be resolved in hand specimens.

Beneath the sediment/pillow basalt sequence are two massive basalt flows separated by a thin sediment layer (Cores 10-12). These form Basaltic Unit 4 in Figure 10. No material from the sediment layer was recovered, but a prominent drop in the integrated bulk density (see logging section) at a drill hole depth which correlates with the lower part of Core 11 attests to its presence. The basalt of these two flows is predominantly fine-grained and microvesicular. There are scattered plagioclase phenocrysts throughout the units, but for the most part the basalt is aphyric. There are numerous fractures throughout these basalts. They contain secondary minerals-chiefly clays and carbonate. Grain size increases from fine to medium in the lower unit. There is very litthe alteration of the basalt despite the presence of numerous carbonate veins. Only the base of the lower basalt flow (the lower $40 \mathrm{~cm}$ ) shows moderate alteration to a general brownish gray color. A layer of silty mudstone showing signs of bioturbation underlies the lower flow. (See section on sediment lithology, this chapter.)

Interbedded spherulitic pillow fragments and microlitic basalts (which may have been pillow interiors) make up the lower portion of the hole (Cores 14-16; Basaltic Unit 5 of Fig. 10). The pillow fragments generally show spherulitic texture adjacent to glassy rinds. Some of the pillow fragments contain small olivine phenocrysts. The more massive basalts are aphyric, slightly altered, and contain varying amounts of vesicles concentrated in patches.

\section{BASALT PETROGRAPHY (HOLE 454A)}

\section{Unit 1-Upper Massive Basalt Flows (Core 5)}

The massive basalts of Core 5 can be subdivided into three zones based on mineral composition and texture of the rocks.

The upper zone (in Core 5, Section 1) is about 1 meter thick and consists of vesicular microphyric basalt with scarce and small (less than 1-to-1.5-mm) microphenocrysts of olivine and plagioclase set in an intersertal or subophitic groundmass. Both types of phenocrysts contain rare inclusions of tiny, euhedral crystals of brown spinel. The groundmass is composed of $25-30$ per cent plagioclase laths (up to $0.6 \mathrm{~mm}$ long; $\mathrm{ca} . \mathrm{An}_{65}$ ), 55-60 per cent granular to plumose augite between plagioclase laths, 3-5 per cent opaque grains (titanomagnetite), and up to 10 per cent devitrified and partly altered interstitial glass.

Round to irregular-shaped vesicles (up to $15 \%$ rock volume) range in size from $0.15-1.6 \mathrm{~mm}$ and are filled or encrusted with palagonite and/or smectite. Patches and irregular veins of these mineraloids also replace the glassy material of the rock groundmass.

The next main zone (Core 5, Sections 2,3 and part of 4 ) is free of phenocrysts and has subophitic, sometimes intersertal texture. It consists of $\mathbf{2 5 - 3 0}$ per cent plagio- 


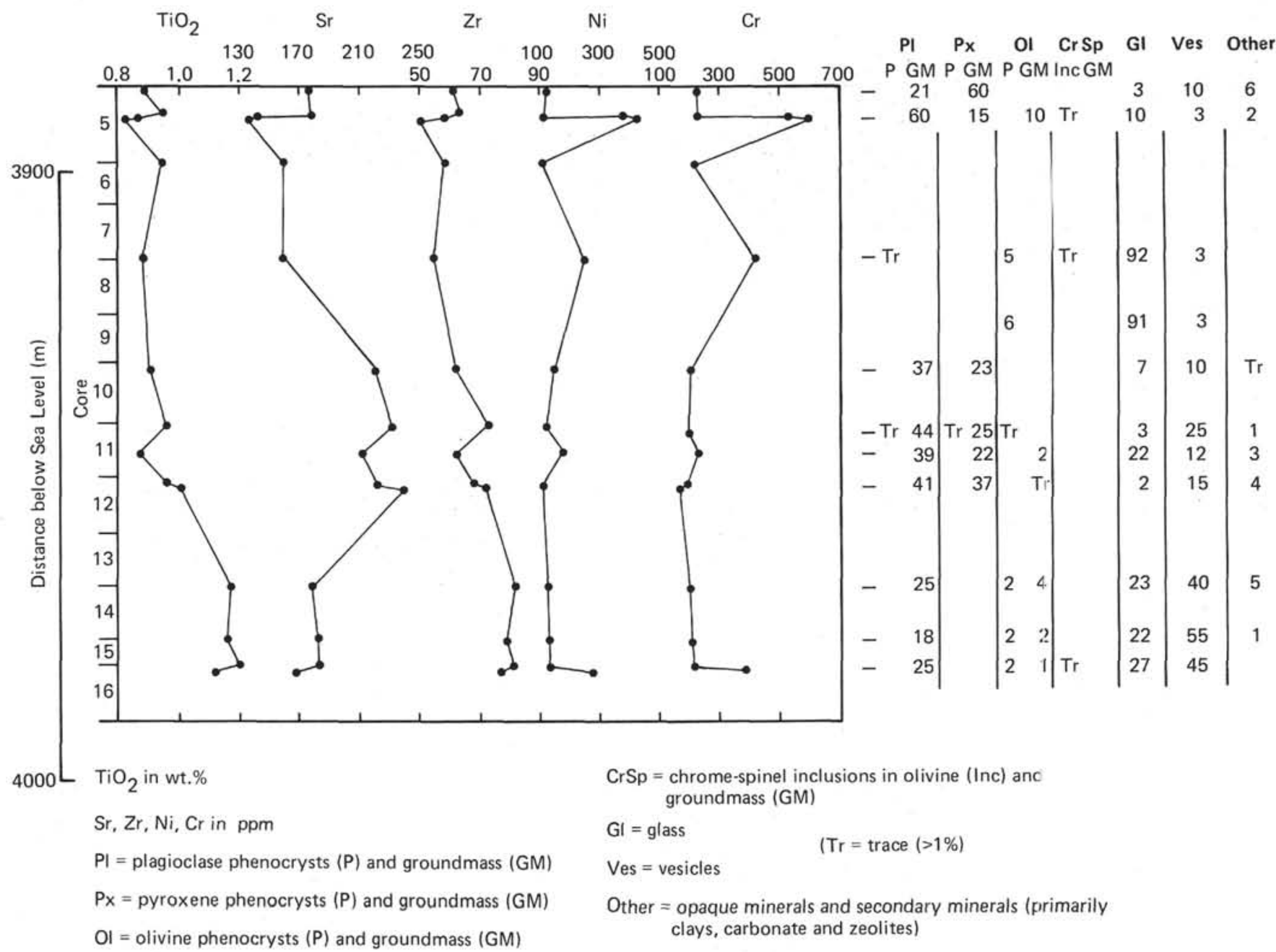

Figure 11. Variation with depth in hole of abundance of $\mathrm{TiO}_{2}, \mathrm{Sr}, \mathrm{Zr}, \mathrm{Ni}, \mathrm{Cr}$, and major phase mineralogy of basalts.

clase (ca. $\mathrm{An}_{65-70}$ ), 50-70 per cent augite, 2-5 per cent opaque, and 5-7 per cent glassy material. Small subangular olivine grains scattered throughout this zone usually contain tiny spinel inclusions. These inclusions are also widespread within the plagioclase laths. The grain size of minerals gradually increases downward to about the bottom of Section 5-3; textures in its lowest parts are microdoleritic. The degree of vesicularity remains constant (10-15\%). In addition to smectite and palagonite, carbonate (aragonite) and zeolites fill vesicles and veins within this interval.

At the top of Section 5-4, the proportion of interstitial material increases somewhat, indicating the base of this subzone was being approached. It was not recovered, however. The rocks in the third subzone (remainder of Section 5-4) are considerably different. They are denser (2-5\% vesicles), more coarse-grained, and enriched in granular olivine crystals (up to $0.6 \mathrm{~mm}$ across; $10-15 \%$ rock volume). In addition to olivine, abundant plagioclase laths (up to $4 \mathrm{~mm}$ long; ca. $\mathrm{An}_{65-70}$ ), pale brown augite (zoned, slightly anomalous interference colors), and minor opaque minerals, are set in a granular to subophitic matrix containing no more than 10 per cent glass. Green, extremely fine grained, clay minerals (smectite) are the principal secondary product after glass. Minute inclusions of brown spinel are rather abundant both in olivine and plagioclase crystals.

\section{Unit 2-Medium-grained Basalt} (Core 6, Sections 2 and $\mathrm{CC}$ )

Several pieces of basalt recovered under the graded drilling breccia are fine to medium-grained, vesicular (up to $15 \%$ ) rocks with aphyric, intersertal or transitional-to-spherulitic textures. These basalts consist of plumose aggregates of plagioclase and clinopyroxene (in the proportion $2: 1$ ) cemented by fresh or partly devitrified and altered glass. Since the recovery is very small, it is difficult to judge from petrographic data whether they represent samples of a chilled massive flow or pillow fragments with disintegrated glassy margins.

\section{Unit 3-Pillow Basalts Interbedded with Sediments (Cores 8 through 10)}

According to logging data, the fragments of pillow basalts with chilled glassy margins recovered in Cores 8 , 9 , and 10 could have been sampled from several (at least four) rather thin (about 0.5 -m thick) pillow units interbedded with sediments. These rocks are slightly vesicular $(\sim 3 \%)$, microphyric in texture, and contain small 


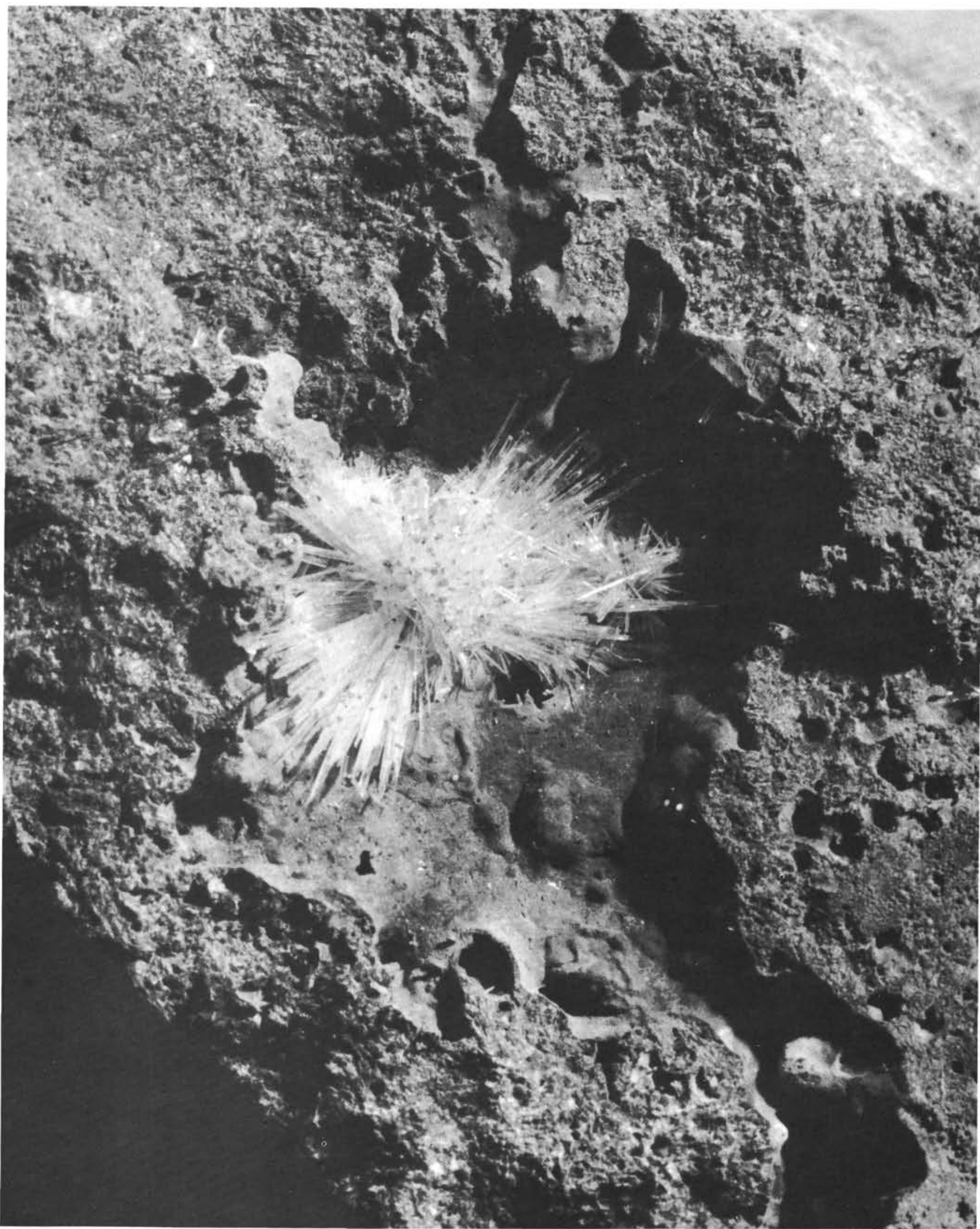

Figure 12. Clump of aragonite crystals in vug on stub of basalt; Section 454A-5-3. Holes in rocks are vesicles $\sim 1$ mm in diameter. Smooth coating on vug surface is green smectites. 
( 0.2 to $0.4-\mathrm{mm}$ ) euhedral olivine microphenocrysts (up to $5 \%$ rock volume) set in a hyaline to spherulitic groundmass.

\section{Unit 4-Massive Basalt Flow (Cores 11 and 12)}

The two separate massive basalt flows (see logging results) of this unit are similar petrographically. They have intersertal outer and subophitic inner zones and do not show internal signs of differentiation. The main components of the rocks are plagioclase laths (50-60\%) up to $1.5 \mathrm{~mm}$ long (ca. $\mathrm{An}_{65}$ ), augite (30-40\%) up to 1 $\mathrm{mm}$ long, minor titanomagnetite, and interstitial glass. Rare small grains of olivine can be seen in thin section of Sample 454A-11-4, 71-75 cm. Tiny brown spinel inclusions are common both in olivine and plagioclase crystals.

These rocks have high porosity as evidenced by vesicles (up to $25 \%$ ), especially in the upper parts of the flows. Abundant round to irregular vesicles $(0.1-7 \mathrm{~mm})$ are encrusted or filled by smectite, zeolite, and carbonate. Smectite also replaces the interstitial material forming green colored patches and irregular zones.

\section{Unit 5-Pillow Basalts (Cores 13 Through 16)}

Only one rock fragment was recovered in the sediment of Core 13-a small piece of pahoehoe. No thin section was made from it.

Two distinct textural groups are observed among the basalt fragments recovered in Cores 14 through 16 .

One group consists of microphyric olivine basalts containing up to 7 percent olivine microphenocrysts $(0.2-$ $0.6 \mathrm{~mm}$; with spinel inclusions) in a slightly porous ( $\sim 3 \%$ vesicles) spherulitic glassy matrix. In hand specimens these usually have well-developed glassy margins or at least glassy remnants. These rocks resembled the olivine pillow basalts of Unit 3 .

The other group of basalts are also olivine microphyric ( $2-3 \%$ rock volume), but their groundmass is intersertal or sometimes transitional to spherulitic. The most crystalline basalts consist of $\sim 3$ percent olivine grains $(0.1 \mathrm{~mm}$ and less in diameter; with spinel inclusions), 55-60 percent plagioclase laths (up to 0.8-1.0 $\mathrm{mm}$ long), and interstitial glassy materials with abundant crystallites of clinopyroxene and dust-like opaque grains. The more crystalline the rock is, the higher is its vesicularity (up to $15 \%$ ).

On the basis of textural characteristics, the rocks of the unit could be interpreted as fragments from the outer (the first group) or inner (the second group) zones of pillows. Unit 5 is thus probably a sequence of pillow basalts.

Many of the rock samples from this unit are moderately altered and have palagonite-smectite aggregates replacing glassy material.

\section{ALTERATION}

Alteration is moderate to minor in the basalts of Hole 454A. The uppermost fine-grained portions of Basaltic Unit 1 in Core 5 are gray-brown in color as opposed to the basic gray of the fresher basalts. One or two pieces have distinct rinds of this brown-stained material. Frac- ture surfaces are thinly coated with rust-colored iron oxyhydroxides, locally flecked with black ferromanganese oxides. Cracks and vugs in Basaltic Unit 1 are lined with green clays or aragonite. In one thin section, a vein of clear orange isotropic palagonite occurs, locally crossing vesicles lined with radially grown fibrous palagonite.

The minor "brown-stone" alteration at the top of Core 5 diminishes with depth. The basalts of Core 11, like those of Core 5, have cracks filled with aragonite (Fig. 12). Green clays with palagonite-like structures can be seen in thin sections of rocks from Core 11: Aragonite is a common secondary mineral throughout these rocks.

Most of the basalts recovered at this site are filled with tiny $(0.5-\mathrm{mm})$ vesicles $(15-20 \%)$, giving them high porosity (they took a long time to dry after splitting). Glassy intersertal patches which contain these vesicles are usually altered to pale fibrous clays. Alteration, though minor, is pervasive, and may give the basalts some of the chemical imprint of sea water.

\section{CHEMISTRY}

Wood et al. (this volume) define three chemical units among the Hole 454A basalts (Fig. 10) and report that they have most of the characteristics of depleted interarc basin tholeiitic basalts. However, trace element data indicate that they have been hybridized to some extent with calc-alkalic materials. Wood et al. (this volume) infer these to be magmas. It seems to us also possible that the basalts may have assimilated sediments of overall calc-alkalic composition, since such sediments clearly were supplied to the site throughout the time of eruption, and consist of air-fall ashes derived from the Mariana arc.

\section{GEOPHYSICS}

Examples of the reflection seismic profiles run across the pond at Site 454 by the Glomar Challenger are shown in Figure 4 . The pond is approximately $2 \mathrm{~km}$ wide from east to west, and over $5 \mathrm{~km}$ wide from north to south. It is surrounded by very steep scarps; the ridge west of the pond (Fig. 4) has an essentially vertical drop of over 700 meters. A prominent, flat, reflector 85 milliseconds below the sea floor $\left(R_{1}\right.$, Fig. 4$)$ correlates with the top of the uppermost basalt flow encountered in the drilling. This reflector, and a similarly pervasive reflector (labeled $R_{2}$ on Fig. 4) at a depth of about 0.15 seconds below the sea floor, are observed on all traverses of the pond. An even deeper reflector $\left(R_{3}\right.$, Fig. 4) is less distinct and can be seen only intermittently.

A prominent mound stands about 40 meters above the sea floor in the middle of the Site 454 pond. It has a basal diameter of about 300 meters, but it is too small to tell much about its shape or whether it is composed of sediment or rocks. It is larger than the geothermal mounds observed in the Galapagos region (Lonsdale, 1977). The mound does not appear to be an almostburied pinnacle of basement rock because it has little effect on the sub-bottom reflectors $R_{1}$ and $R_{2}$. Holes 454 and $454 \mathrm{~A}$ are located within 300 meters of the mound. 
There are no faults observed in the sediment pond. The sea floor and reflectors $R_{1}$ and $R_{2}$ all dip slightly to the west.

\section{PALEOMAGNETISM}

Site 454 is situated on a negative magnetic anomaly adjacent to the western flank of the possible central anomaly over the axial graben in the Mariana Trough. A magnetic basement age of about 1.2 to $1.6 \mathrm{~m} . \mathrm{y}$. (first half of the Matuyama reversed epoch) is inferred from this negative anomaly, although correlations with adjacent tracks have been discouragingly unsuccessful.

Sediments at this site were too disturbed for paleomagnetic study, except for three mudstone beds interlayered in the basaltic basement. On the basis of differences in magnetic inclination, the basalts are separated into five groups (Fig. 10). Each unit sampled contains rocks of distinct magnetic inclination, with the exception of Unit 4. Samples from the upper portion of Unit 4 have slightly greater inclination than those from the lower portion. The three mudstone beds and five igneous units all show a negative stable inclination (for more details, see Bleil, this volume).

\section{PHYSICAL PROPERTIES}

Compressional wave velocity, wet-bulk density, saltcorrected water content, porosity, acoustic impedance, and thermal conductivity were determined for cores recovered from Holes 454 and 454A. Measurements are tabulated in Table 2 and plotted against depth in Figure 13.

\section{Sonic Velocities}

Sonic velocities for the vertical direction were measured in the Hamilton Frame. Velocities in the sediments range from 1.52 to $2.32 \mathrm{~km} / \mathrm{s}$, showing no increase in depth in the first 40 meters below the sea bed, but progressively increasing with depth when overlain by basalts (Fig. 13). Velocities in the basalts range from 3.65 to $5.12 \mathrm{~km} / \mathrm{s}$, showing no relationship with depth but correlating with porosity and density (Figs. 14 and 15). It is likely that the higher-velocity basalts come from the more massive rocks of the interior of lava flows.

\section{Densities}

Wet-bulk densities were determined both by 2 -minute GRAPE counts and by gravimetric method. The average discrepancy between the two methods is $0.06 \mathrm{~g} / \mathrm{cm}^{3}$. As with the sonic velocities, no conspicuous trend with depth is noticeable in the top 40 meters of the column. The limited number of measurements on the vitric ashes and mudstones intercalated with the basalts, however, showed density increasing with depth (Fig. 13).

\section{COMPARISON OF LABORATORY MEASUREMENTS WITH DOWNHOLE LOGGING}

Laboratory measurements of wet-bulk density are plotted on the downhole compensated density log in Figure 16. The depth at which a laboratory value is plot- ted is derived from its position within the recovered core. This can be in error by several meters, particularly when the recovery is low. Furthermore, the density logging tool averages over a depth range of about $0.3 \mathrm{me}$ ters, so that small fragments of basalt that are large enough to measure in the laboratory may not be detected. These factors may explain the discrepancy observed between downhole and laboratory values at 3942 meters in Figure 16. In general, The agreement between laboratory and downhole logged densities is excellent.

Laboratory measurements of sonic velocity are plotted on the sonic log in Figure 17. Here the agreement is less good than in the density case. Measurements on basalt samples are higher, and on sedimentary samples are lower, than the corresponding downhole values. These discrepancies may be explained by the following:

1) The sonic log determines interval time (1/velocity) over a 2 -ft $(0.6-\mathrm{m})$ depth range. However, unlike the density log which is pressed against the side of the hole, the sonic tool is free to move with the end of the logging cable. The heave of the ship will thus induce an up-anddown motion in the sonic tool as it progresses up the hole. The effect of this will be to make the sonic log average over a greater depth range than its receiver spacing, probably in the range of 1 to 2 meters. Thus, in formations consisting of a smaller-scale mixture of heterogeneous rocks (such as the basalt pillow fragments and vitric mudstones recovered in Cores 8 and 9) the velocity logged is likely to be an average for the rock types encountered. Only when homogeneous formations thicker than 1 to 2 meters are encountered can the sonic log make an accurate measurement of the in situ velocity of the particular rock type. This appears to be the case for the massive basalt lavas encountered between 3947 and 3962 meters below the drill floor (Fig. 17).

2) The sedimentary rock samples measured were vitric mudstones and tuffs, which have had porosities in the range of $60-70 \%$. The recovery of these samples involved a reduction in pressure from about 400 bar to 1 bar. Since water is much more compressible than rockforming minerals, the water held in the rocks must (1) have expanded within the rock, thus increasing its porosity, and/or (2) have partially escaped from the rock, possibly destroying some of the rock fabric in the process. In either case, the sonic velocity of the rock is likely to have been reduced.

3) Basalt samples selected for measurement in the Hamilton Frame were necessarily coherent pieces of rock which were sawn into parallel-sided slabs. The porosity of these samples is confined to the vesicles they might contain. On the scale of the downhole velocity logging, fissures and cracks are likely to be important. Indeed, there were mineralized fissures and cracks in many of the recovered cores. Thus laboratory measurements of sonic velocity in basalt samples are likely to exceed those observed on a larger scale in situ.

\section{Thermal Conductivity}

Many thermal conductivity measurements were made on the core samples recovered from Holes 454 and $454 \mathrm{~A}$. The results indicate that the thermal conductivity 
Table 2. Physical properties measurements, Site 454.

\begin{tabular}{|c|c|c|c|c|c|c|c|c|}
\hline $\begin{array}{c}\text { Sample } \\
\text { (Interval in cm) }\end{array}$ & $\begin{array}{l}\text { Depth } \\
\text { (m) }\end{array}$ & $\begin{array}{l}\text { Sound } \\
\text { Velocity } \\
\text { (vertical) } \\
(\mathrm{km} / \mathrm{s})\end{array}$ & $\begin{array}{c}\text { GRAPE } \\
\text { 2-minute } \\
\text { Wet-Bulk } \\
\text { Density } \\
\left(\mathrm{g} / \mathrm{cm}^{3}\right)\end{array}$ & $\begin{array}{c}\text { Water } \\
\text { Content } \\
\text { (salt- } \\
\text { corrected) } \\
(\%)\end{array}$ & $\begin{array}{c}\text { Porosity } \\
(\%)\end{array}$ & $\begin{array}{l}\text { Wet-Bulk } \\
\text { Density } \\
\left(\mathrm{g} / \mathrm{cm}^{3}\right)\end{array}$ & $\begin{array}{c}\text { Acoustic } \\
\text { Impedance } \\
\left(\mathrm{g} / \mathrm{cm}^{2} \mathrm{~s} \times 10^{5}\right)\end{array}$ & $\begin{array}{l}\text { Rock } \\
\text { Type }\end{array}$ \\
\hline \multicolumn{9}{|l|}{ Hole 454} \\
\hline $3-1,99-101$ & 10.99 & 1.53 & 1.57 & 56.0 & 77.2 & 1.41 & 2.16 & Soft mud \\
\hline $3-3,56-58$ & 13.56 & 1.55 & 1.72 & 42.3 & 66.8 & 1.62 & 2.51 & Firm mud \\
\hline $4-1,77-79$ & 20.27 & 1.54 & 1.55 & 50.7 & 73.6 & 1.49 & 2.29 & \\
\hline $4-3,122-125$ & 23.72 & 1.52 & 1.30 & 60.9 & 80.5 & 1.36 & 2.07 & Firm clay \\
\hline $4-5,102-104$ & 26.52 & 1.52 & 1.36 & & & & 2.07 & \\
\hline $5-3,106-108$ & 33.06 & 1.54 & 1.33 & & & & 2.05 & Soft mud \\
\hline $5-5,106-108$ & 36.06 & 1.52 & 1.41 & 56.6 & 78.1 & 1.41 & 2.14 & Firm clay \\
\hline \multicolumn{9}{|l|}{ Hole 454A } \\
\hline $1-1,77-79$ & 1.27 & 1.52 & & & & & & Mud \\
\hline $2-2,103-105$ & 41.03 & 1.53 & 1.43 & & & & 2.19 & \\
\hline $5-2,49-52$ & 68.99 & 4.07 & 2.45 & 10.6 & 25.1 & 2.42 & 9.85 & Basalt \\
\hline $5-4,11-13$ & 71.61 & 5.09 & 2.66 & & & & 13.5 & Basalt \\
\hline $6, C C, 18-20$ & 79.32 & 4.26 & 2.51 & 9.9 & 23.7 & 2.45 & 10.4 & Basalt \\
\hline $8-1,119-121$ & 96.19 & 1.85 & 1.56 & & & & 2.89 & Vitric ash \\
\hline $8-2,20-22$ & 96.70 & 1.74 & & 45.9 & 69.2 & 1.55 & 2.70 & Vitric ash \\
\hline $10-1,41-42$ & 113.41 & 3.71 & 2.21 & 15.4 & 33.6 & 2.24 & 8.31 & Basalt \\
\hline $11-2,44-46$ & 123.94 & 4.21 & 2.25 & 12.8 & 29.0 & 2.32 & 9.77 & Basalt \\
\hline $11-4,37-43$ & 126.87 & 4.28 & 2.43 & & & & 10.4 & Basalt \\
\hline $12-2,5-7$ & 132.55 & 3.65 & 2.20 & 15.6 & 33.9 & 2.23 & 8.14 & Basalt \\
\hline $13-1,6-10$ & 140.06 & 2.11 & 1.69 & & & & 3.57 & Vitric mud \\
\hline $13-1,84-86$ & 140.84 & 2.32 & & & & & & Vitric mud \\
\hline $14-1,63-65$ & 149.63 & 5.12 & 2.48 & & & & 12.7 & Basalt \\
\hline $16-1,81-83$ & 162.81 & 4.90 & 2.47 & 10.0 & 23.8 & 2.44 & 12.0 & Basalt \\
\hline $16-2,2-4$ & 163.52 & 4.49 & 2.37 & & & & 10.6 & Basalt \\
\hline
\end{tabular}

a Porosity $=$ salt-corrected water content $\times$ wet-bulk density (gravimetric) $/ 1.025$.

b Gravimetric method.

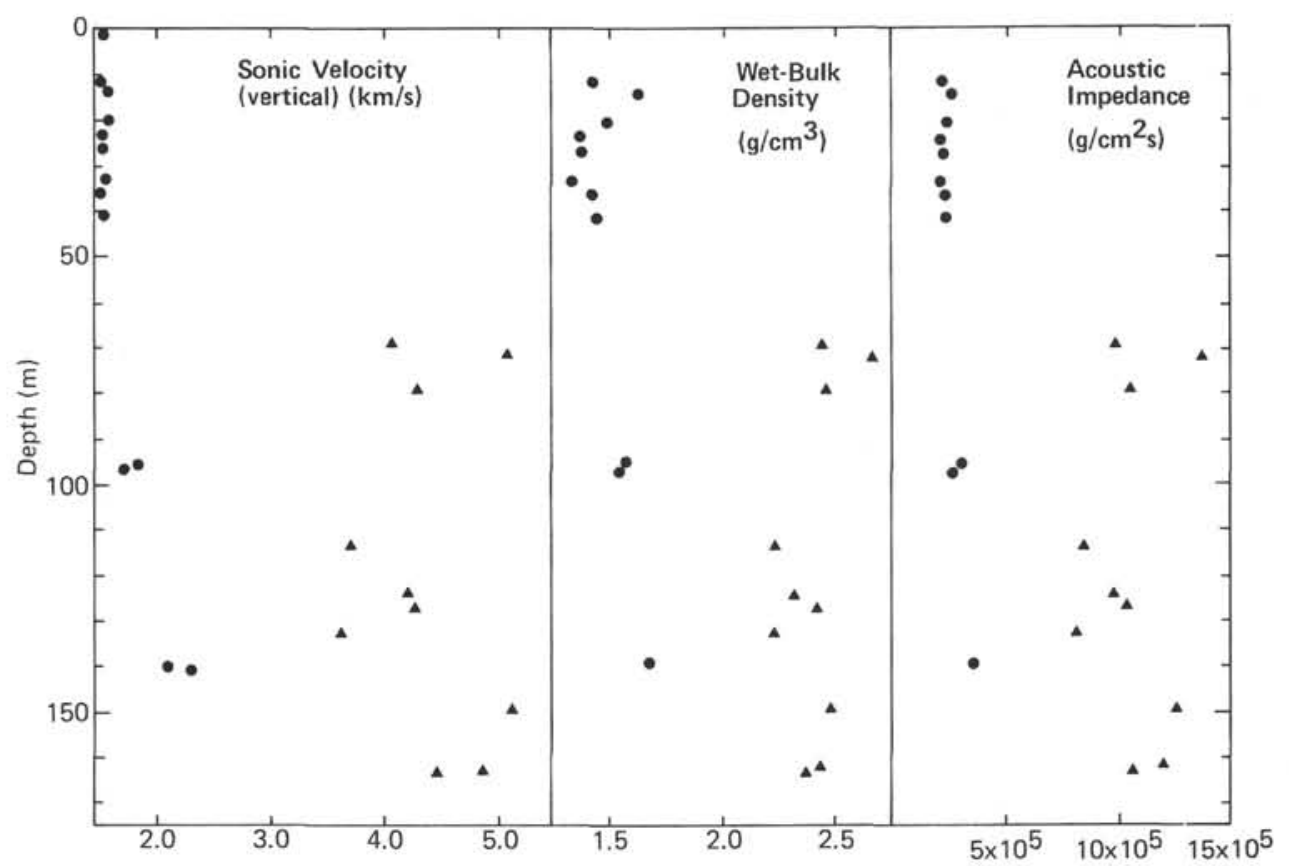

Figure 13. Physical properties versus depth, Holes 454 and $454 \mathrm{~A} ; \bullet=$ sediments, $\boldsymbol{\Delta}=$ basalts

of the sediment at Site 454 is generally higher than at Site 453 . This difference may be related to the shallower depth at Site 454. The rate of increase of thermal conductivity with depth was found to be the same as at Site 453.

The basaltic samples from the basement in Hole 454A showed a fairly uniform thermal conductivity. More details and discussions on the measurements are given in Horai (this volume).

\section{LOGGING}

A complete series of downhole logs for Site 454 were obtained. Preliminary correlation of the logs with other data are included in the appropriate sections of this chapter.

In addition to the inherent resolution of each of the types of logs, two other points should be remembered when making geologic interpretation from the logs:

1) The logging tool will be moving up and down in the hole in response to the heave of the drilling vessel. This heave is on the order of \pm 1 meter during the moderate seas encountered during Site 454 logging operations. The heave at the logging tool will be heightened or damped to an unknown degree as a function of the elastic properties of the logging wire and friction in the pipe. The bottom of the drill pipe will also heave with 


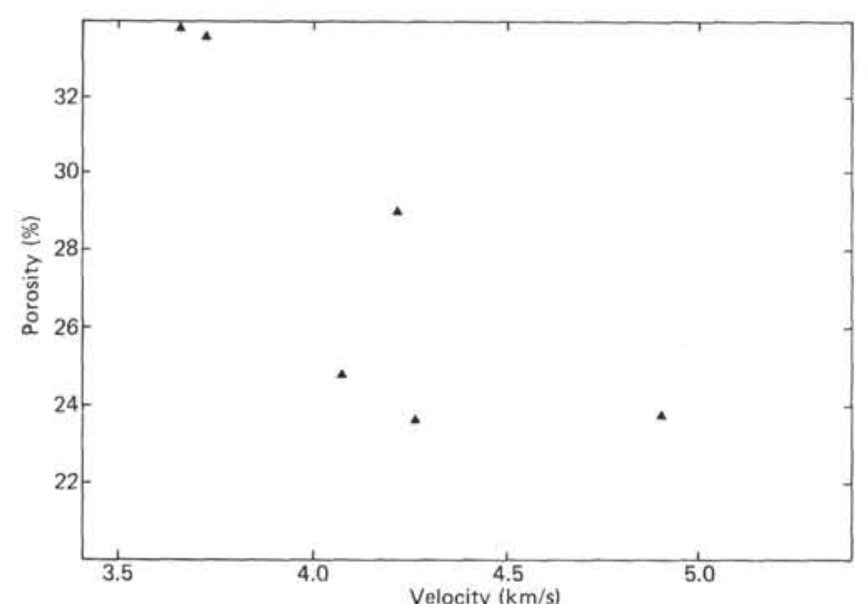

Figure 14. Comparison of sonic velocities and porosities of basalts, Hole 454A.

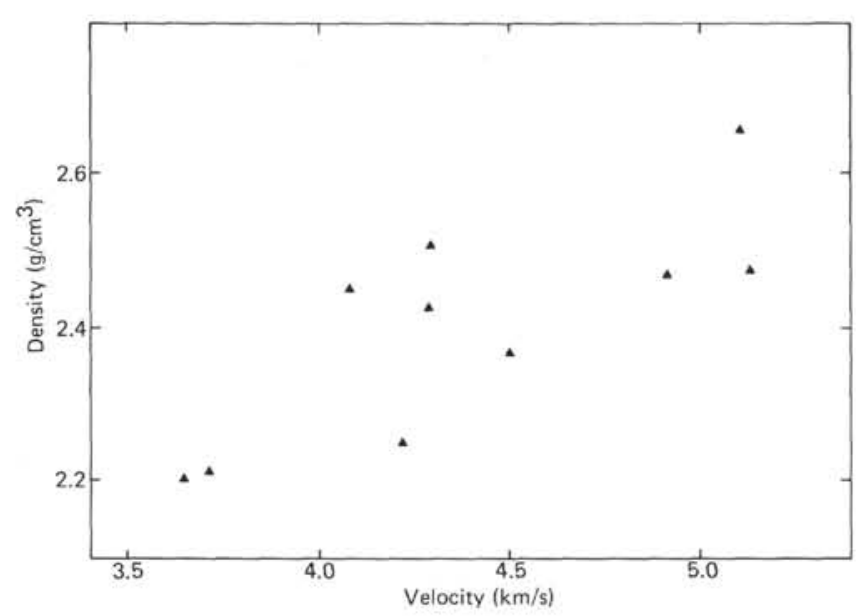

Figure 15. Comparison of sonic velocities and 2-minute GRAPE densities for basalts, Hole 454A.

the ship, but perhaps not in phase with the logging tool because of the different elastic properties of the pipe and the logging cable.

2) The bottom of the hole is the level to which the hole caved in after lifting the bit. It is different for different shapes and weights of the logging tools, so it should not be used as a fixed datum.

The logging proved invaluable for reconstructing the stratigraphy of Site 454 , where core recovery was not very good.

\section{HEAT FLOW}

Two downhole temperature measurements were attempted in Holes 454 and 454A. The measurement conducted in soft mud in Hole 454 at a sub-bottom depth of 27 meters was unsuccessful.

In Hole 454A, we decided not to attempt any heat flow measurements until the bottom-hole assembly was completely buried in order to protect the drill string. Unfortunately, by the time the bottom-hole assembly was buried the bit was penetrating interbedded basalt and sediments, which made the heat flow measurement impossible.

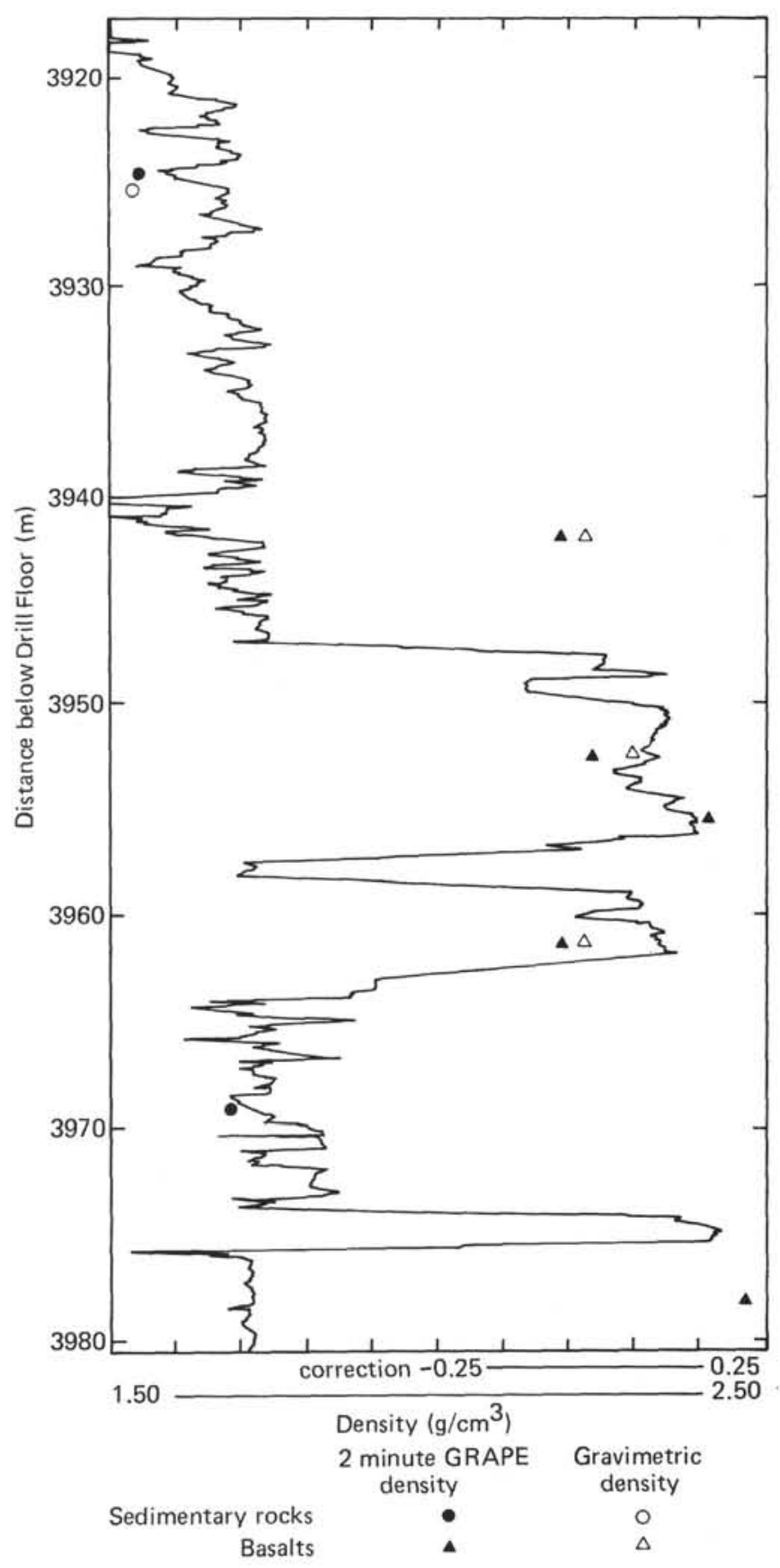

Figure 16. Comparison of laboratory density measurements with downhole compensated density log, Hole 454A.

After drilling in Hole 454A ended, we made a bottomhole water temperature measurement using the Tokyo T-probe. Later, two lowerings of the Gearhart-Owen logging tool were made. All these measurements revealed a remarkably small temperature rise in the hole.

The observed low gradient in Hole 454A was probably not due to the effect of thermal disturbance by drilling and circulation of mud (water), because there was not enough change in temperature with time after the drilling ceased.

If we take the mean of the observed temperature gradient $\left(0.2^{\circ} \mathrm{C} / 100 \mathrm{~m}\right)$, and interpret it as the geothermal 


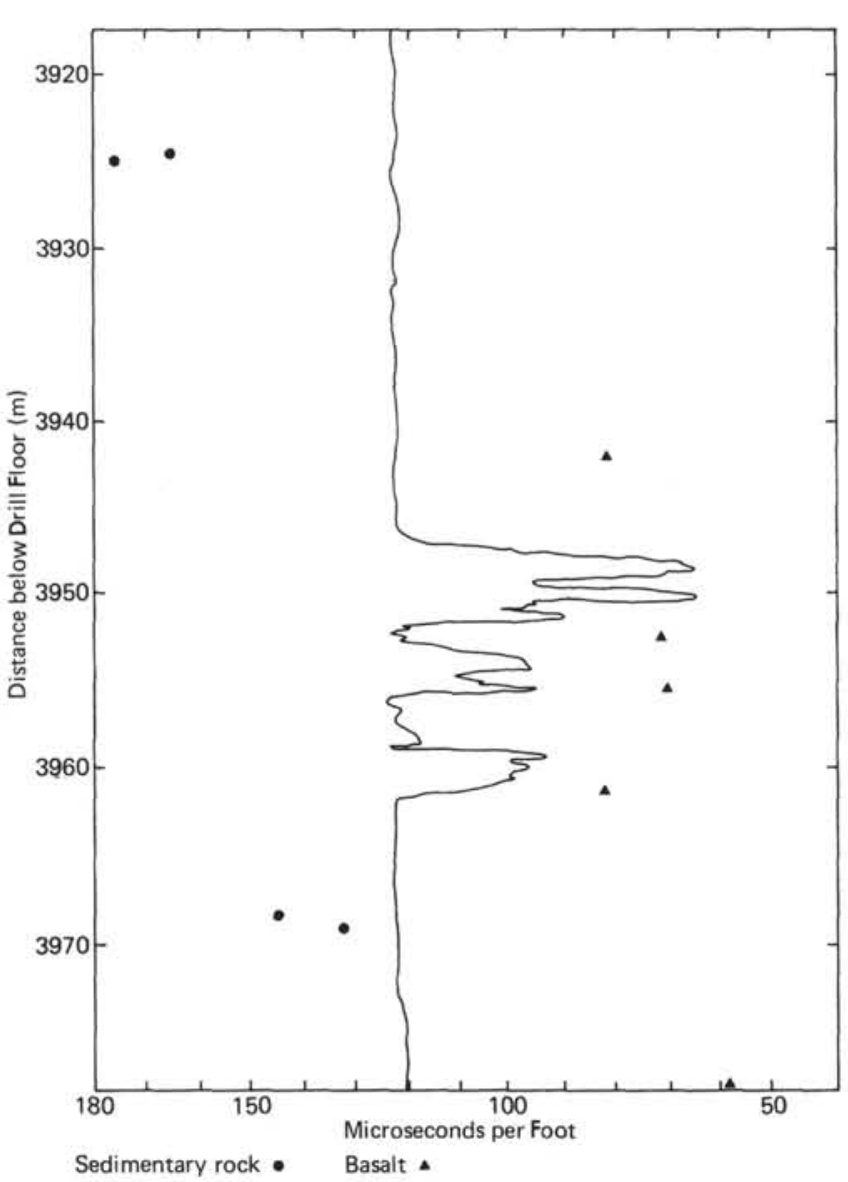

Figure 17. Comparison of laboratory measurements of sonic velocity with bore-hole compensated sonic log, Hole 454A.

gradient, the apparent heat flow in Hole $454 \mathrm{~A}$ is calculated as: $Q=0.06$ HFU.

An entirely different interpretation for the low temperature gradient observed in Hole $454 \mathrm{~A}$ is also possible. It may be that cold sea water was continuously drawn into the hole after the drill penetrated into the highly permeable igneous basement and this artificially induced circulation of sea water cooled the entire hole. For more details, see Uyeda and Horai (this volume).

\section{LARGE-SCALE RESISTIVITY}

Hole $454 \mathrm{~A}$ provided the first opportunity to try the large-scale resistivity experiment. Only about 70 meters of open hole was available for logging beneath the end of the drill pipe-too short a distance to provide a proper test of the resistivity experiment. Nevertheless, the results gave values similar to those obtained with the electrical resistivity log (Francis, this volume).

\section{SUMMARY AND CONCLUSIONS}

The major objectives of drilling at Site 454 were to determine: (1) the age, state and petrologic characteristics of the youngest "drillable" back-arc basin crust formed at a well-developed stage of spreading; and (2) the history of the sedimentary, volcanic, tectonic, and thermal activity in the area of the youngest "drillable" back-arc basin.
Being the youngest back-arc crust also means that Site 454, of all our Mariana Trough sites, formed at the greatest distance from the active subaerial volcanos on the Mariana arc.

The age of the deepest sediments suggests that the first basalt flow encountered in Hole 454A, at the age of the sediments intercalated between the deeper basalt flows, is 0.9-1.6 m.y. This fits the age of 1.2-1.6 m.y. calculated from the surface magnetic anomaly pattern (Bleil, this volume). Paleomagnetic measurements of the three mudstones between the basalt flows, and of the five basalt units, all gave stable negative inclination in agreement with the surface anomaly. The overlap of the ages (1.2-1.6 m.y.) provides a maximum halfspreading rate from the Trough spreading center of $1.7-2.3 \mathrm{~cm} / \mathrm{y}$., although the accuracy of such an estimate is poor because of the short distances and times involved. Nevertheless, the spreading rates agree with those estimated for Site 453, supporting the idea that the back-arc basin spreading is slow and likely originates at the graben $28 \mathrm{~km}$ east of Site 454 .

The basalts in Hole 454A show only minor alteration, and are chemically similar to depleted inter-arc basin and mid-oceanic ridge tholeiites. The different flows have distinct chemical and, to some extent, petrographic characteristics. Their chemistry appears to reflect a varying degree of hybridization, possibly caused by mixing with calc-alkalic material (Wood et al., this volume).

On the basis of the reflection seismic records and the relief surrounding the pond, we suspect that the interbedded basalt and sediment sequence extends far deeper than we were able to sample. The presence of thick interbedded sediments in the upper part of the crust implies a very high sedimentation rate in the basin during its earliest history. If the sediments are derived from airor water-borne volcanoclastics from island arc volcanism, interbedded sediments should be thickest in the older parts of the back-arc basin that formed when the distance from the volcanics to the spreading center is the smallest. We have no evidence whether or not this is the case.

The nature of the 40-meter mound in the center of the Site 454 pond remains a mystery. It could be the top of a narrow pillar of basalt that was extruded after rising through the sediments and basalt flows in the pond. It might also be a small horst, although there is no other sign of faulting cutting the deposits in the Site 454 basin. It is tempting to speculate that, in light of the high level of geothermal activity in the Mariana Trough (see chapters on Sites 454 and 457), the mound is an oversized version of the geothermal mounds in the Galapagos area. No other direct evidence for active geothermal activity is apparent at Site 454, but Hobart et al. (1979) found very high and very variable heat flow near this site. If we are correct that there is a considerable thickness of interbedded sediment and basalt flows beneath where we were able to penetrate, then our cored section might be isolated from nearby geothermal activity.

The very low heat flow measured at Site 454 (0.06 HFU) could be representative of a local extreme value, but we prefer to regard it as evidence of cool sea water 
being drawn into the drill hole and flowing into permeable beds deep in the hole. It is not caused by drilling disturbance.

\section{REFERENCES}

Bibee, L. D., 1979. Crustal structure in areas of active crustal accretion [Ph.D. dissert.]. University of California, San Diego.

Bukry, D., 1975. Coccolith and silicoflagellate stratigraphy, northwestern Pacific Ocean, Deep Sea Drilling Project, Leg 32. In Larson, R. L., Moberly, R., et al., Init. Repts. DSDP, 32: Washington (U.S. Govt. Printing Office), 677-701.
Hobart, M. A., Anderson, R. N., and Uyeda, S., 1979. Heat transfer in the Mariana Trough. EOS, 60:383.

Karig, D. E., 1971. Structural history of the Mariana Island Arc System. Geol. Soc. Am. Bull., 83:323-344.

Lonsdale, P., 1977. Deep-tow observations at the Mounds Abyssal Hydrothermal Field, Galapagos Rift. Earth Planet, Sci. Lett, 36:92-110.

Nigrini, C. A., 1971. Radiolarian zones in the Quaternary of the equatorial Pacific. In Funnel, B. M., and Riedel, W. R. (Eds.), The Micropaleontology of Oceans: London (Cambridge University Press), pp. 443-461. 


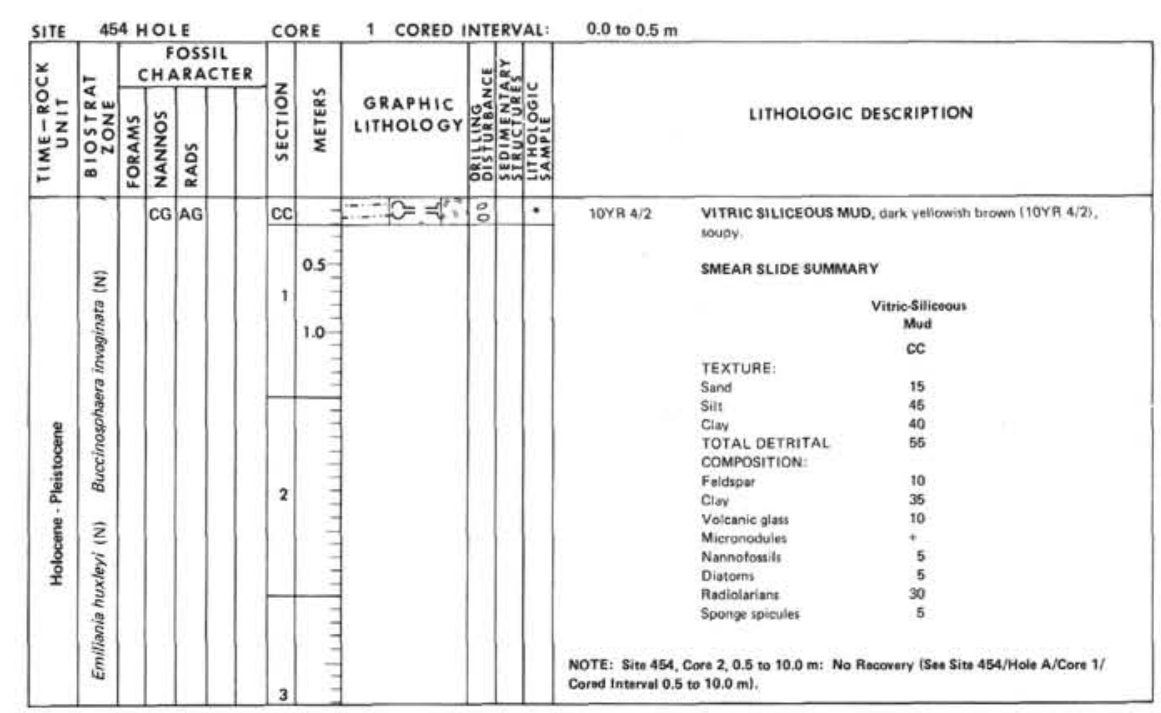

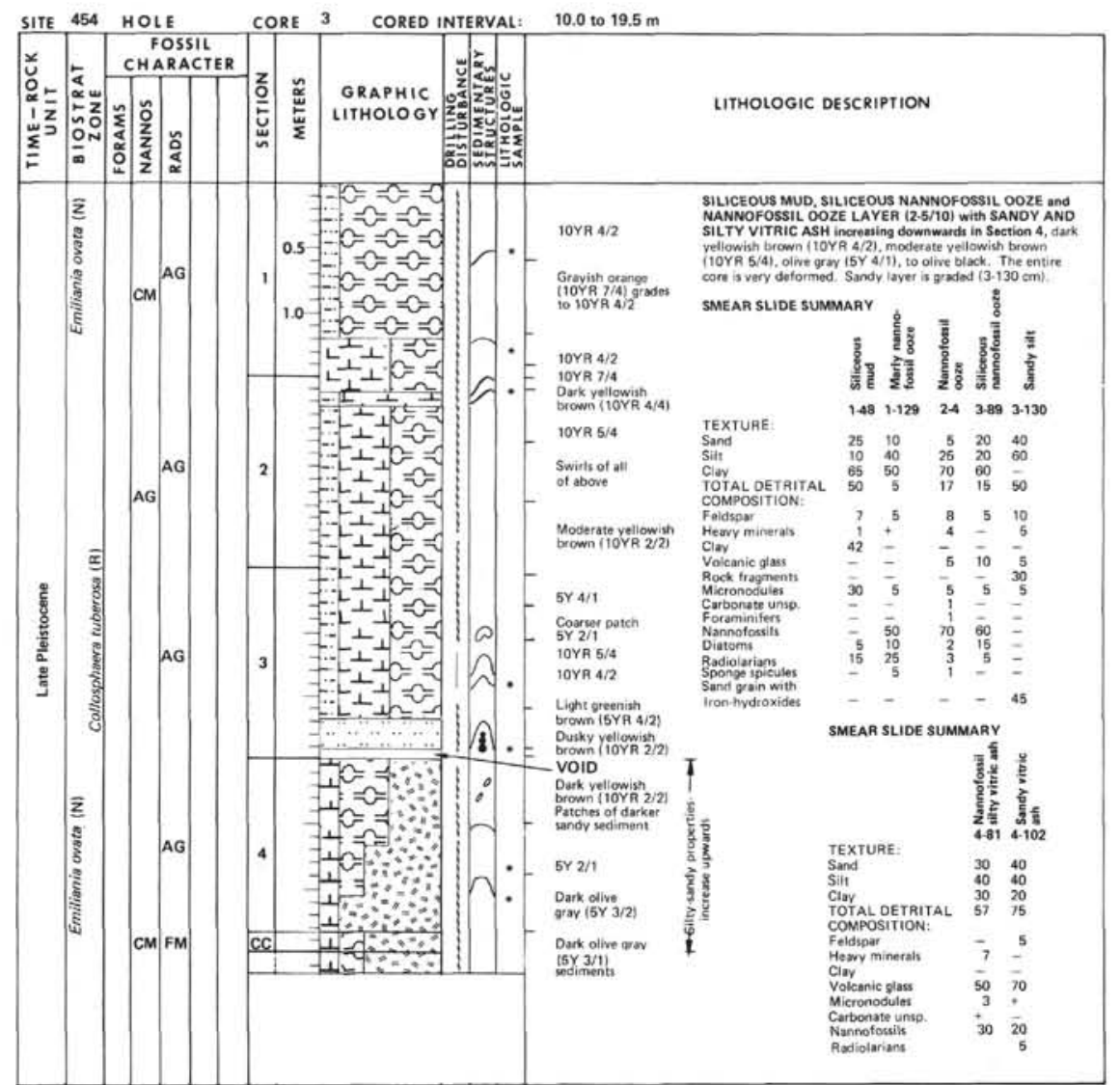



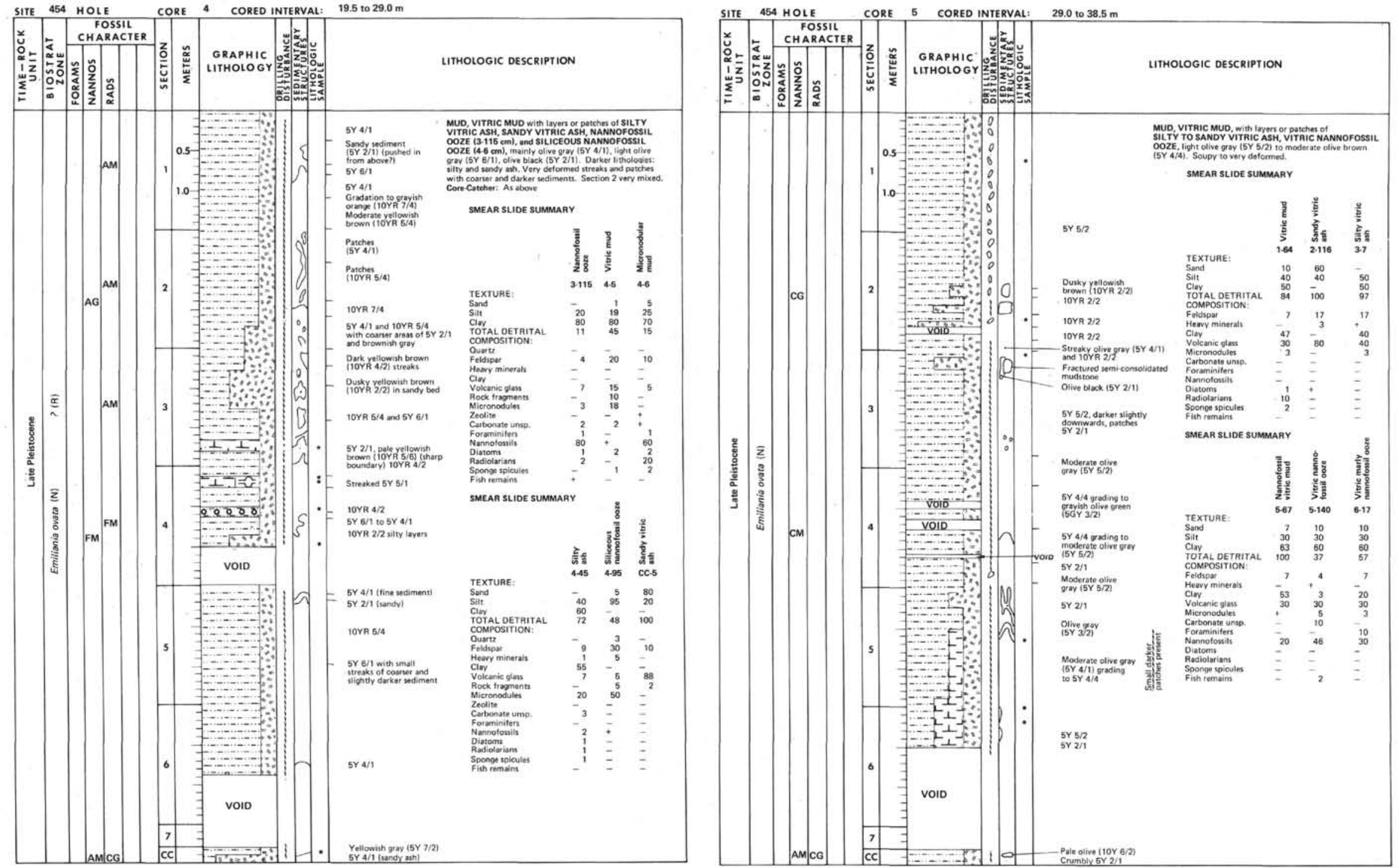

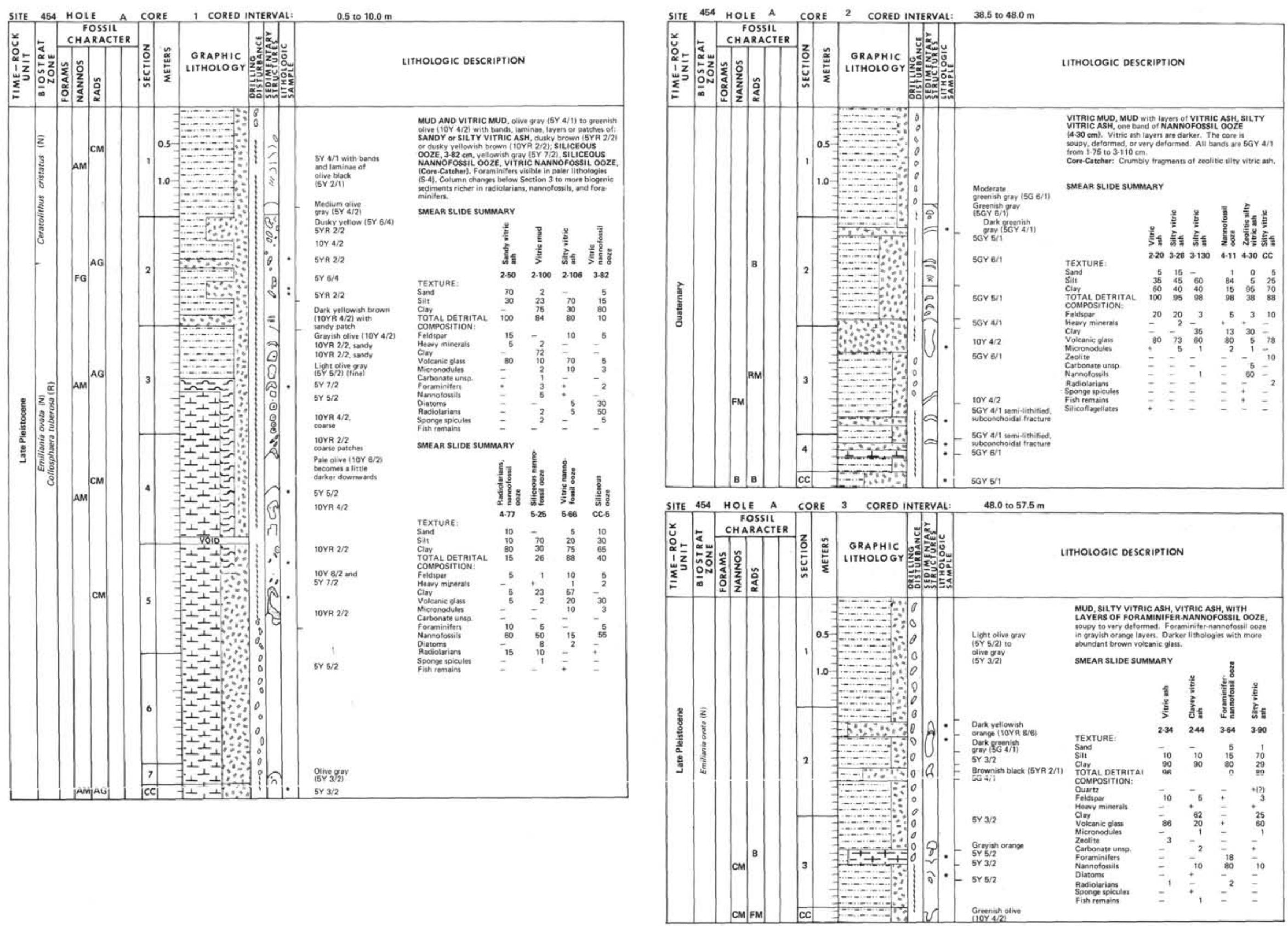


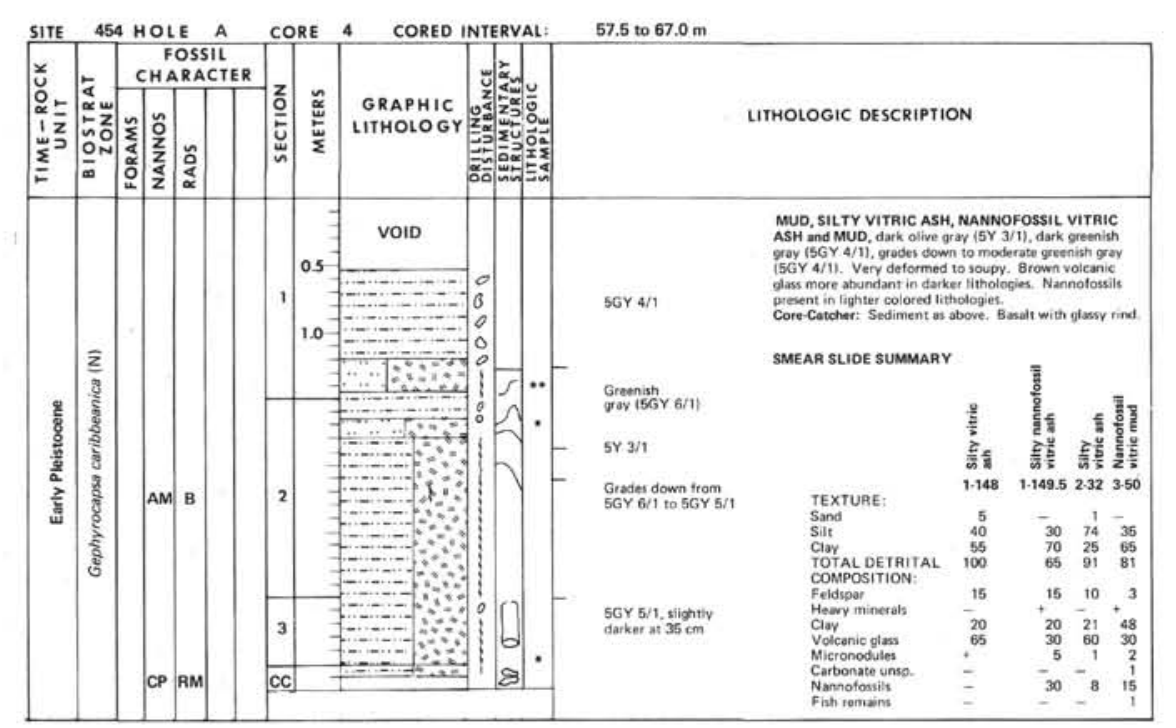




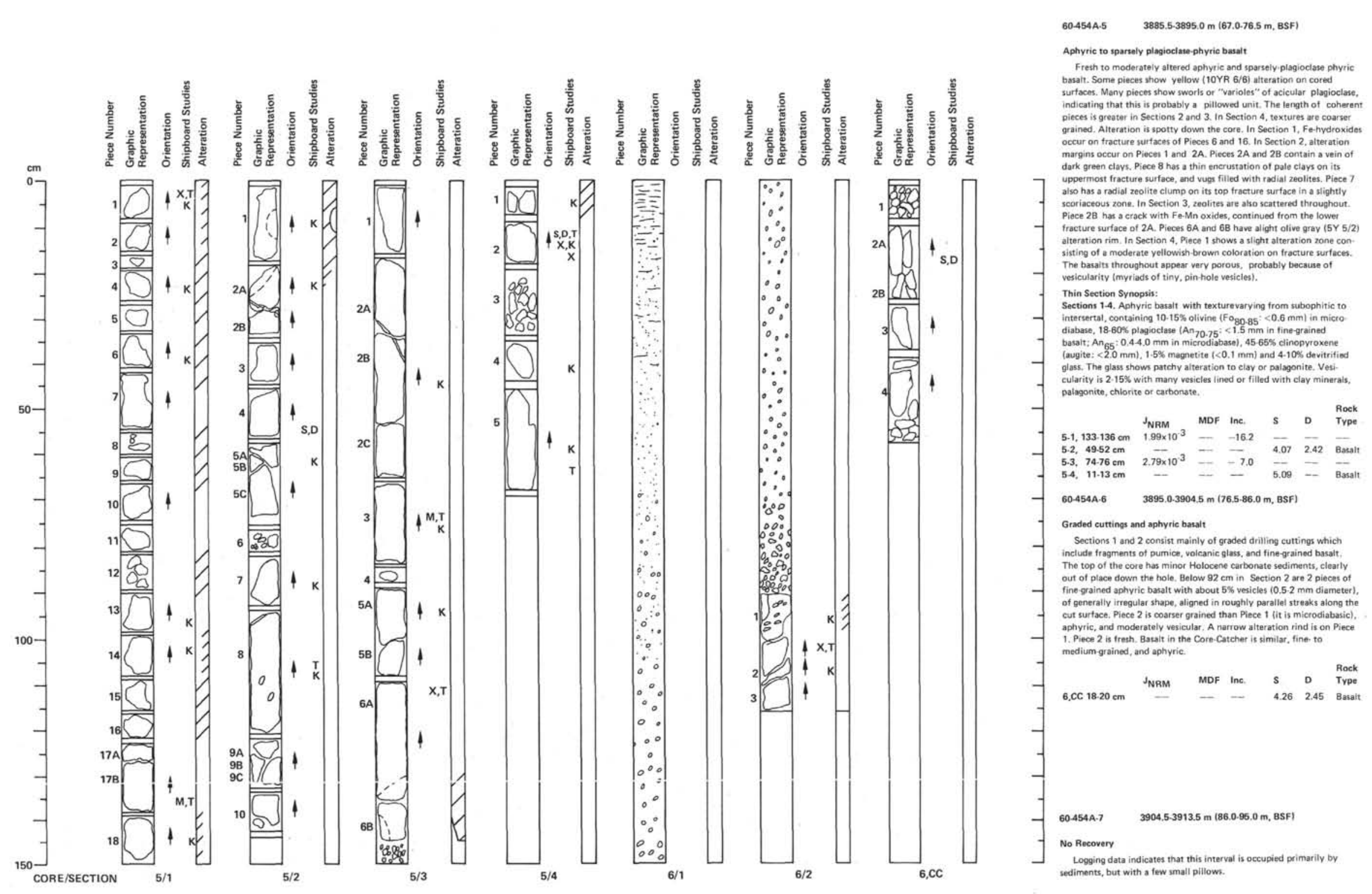




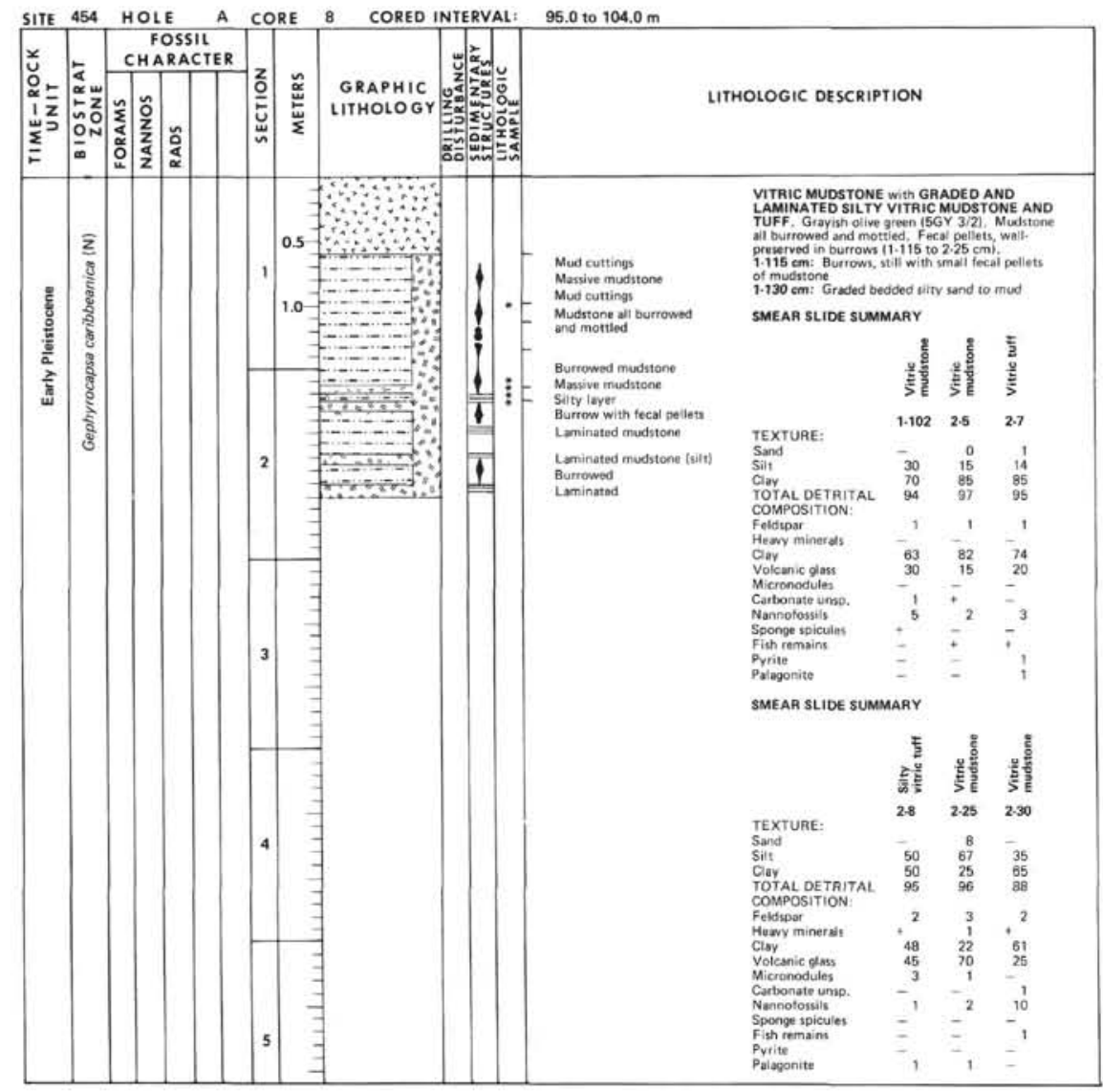




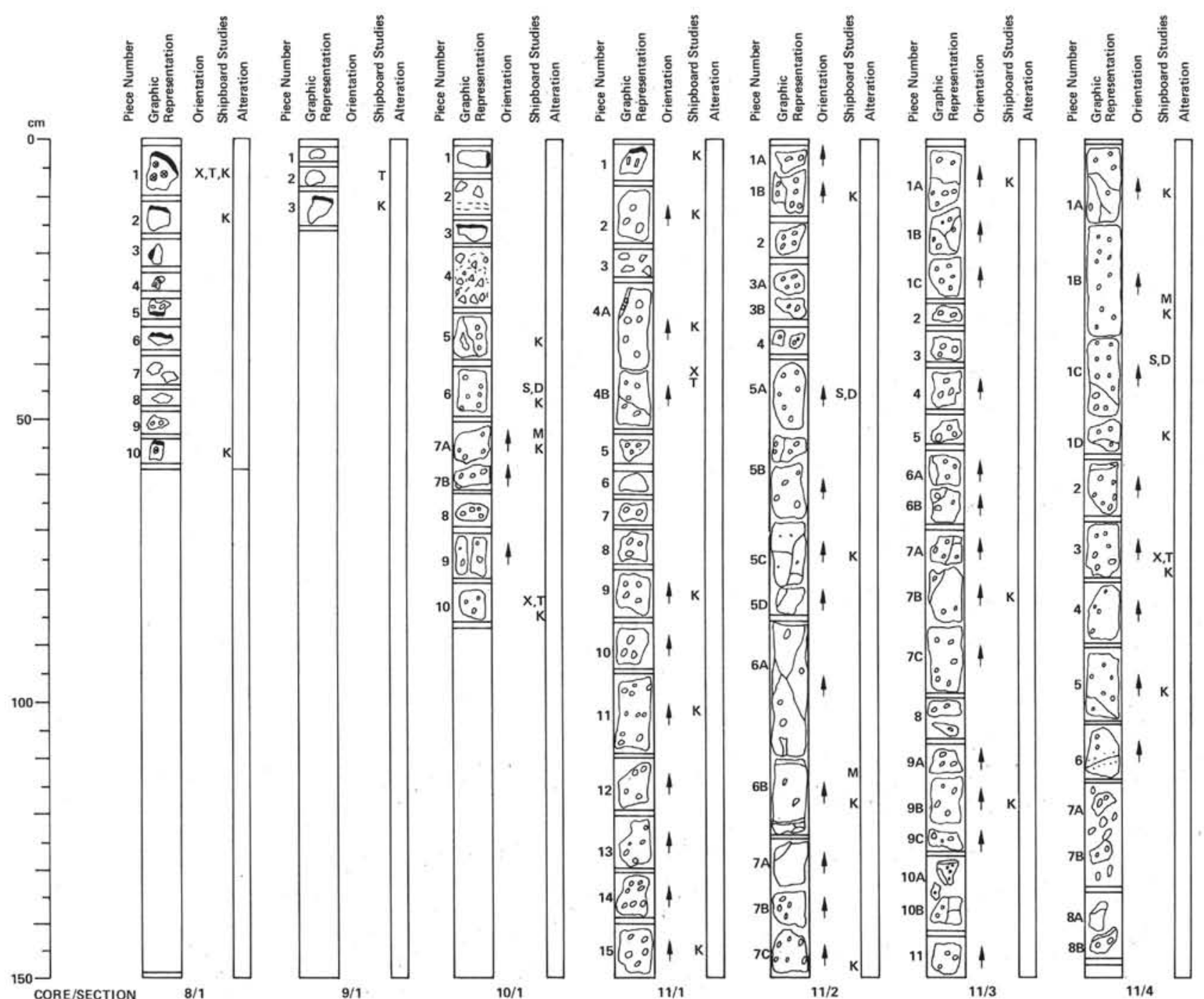

60.454A.8

$3913.5-3922.5 \mathrm{~m}[95.0 \cdot 104.0 \mathrm{~m}, \mathrm{BSF}$

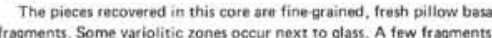
have irregyuarly shaped vesicles $(0.5-2 \mathrm{~mm})$. Logging indicates that th and by lesser amounts of basalt.

8.1, 1.3 cm No. 1. Microporphyritic basalt with 4X euhedral olvine crystals $(0.2-2.4 \mathrm{~mm}$ ) and $93 \%$ glass. The glass is devitrified and con.

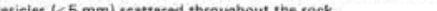

60.454A.9 $\quad 3922.5-3931.5 \mathrm{~m}$ (104.0.113.0 m, BSF

Aphyric bestie

Three piceses of fine: to medium-grained, dark gray to black, aphyrtc pillow basalt fragments were recovered. All are fresth, Piece 3 has a giassy rind. Vesicles are generally absent. Logging data indicates that these are intersediment pillow

Thin Section Description

tic bosalt with 58 euhedrat olivine

devitifified glass. Vosicularity it $3 \%$ with round to oval vesicles, some

60454A. $10 \quad 3931.53940 .5 \mathrm{~m}(113.0122 .0 \mathrm{~m}, \mathrm{BSF})$

Aphyric basalt

Fine to medium grained, gray to bluish gray, vesiculata, aphyric tresh basalt, with mierolitic plagioclase in coarser grasined piecess. Several pieces have carbonate-clay veins which do not alter into the

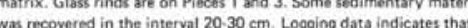
several meters ot the top of the interval of this core are prinserily Thin Section Description
$101,81.84 \mathrm{~cm}$ No. 10 . Aphyric basalt with interstitial to subophitic pyroxeng (augite: $<0.6 \mathrm{~mm}$ ), $1 \%$ magnetite, and $7 \%$ alass

J J MDF Ine $S$ D Rock

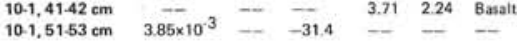

60.45AA.11 $3940.53949 .5 \mathrm{~m}(122.0 .131 .0 \mathrm{~m}$, BSF $)$

Aphyric basalt

m. grained aphyric vesicular dark gray basalt, generatily lacking glassy rindi. The basalts are not significantly altered although veins of greenish clays are present in Sections T and 4, carbonate veins
in Sections 2-4, and sprays of zeolite and prehnite? (?) in Section 3. One apparently oxidized when

Thin Section SYnopssis
$111 \cdot 1,4044 \mathrm{~cm}$ No. $4 \mathrm{~B}$ and $114,41 \cdot 75 \mathrm{~cm}$ No. 3. Microporphyritic

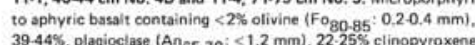
(augite: $<1 \mathrm{~mm}$. $1.2 \%$ magnetite $<0.1 \mathrm{~mm}$ ) and $5.22 \%$ devitriffed glass. The glass is partially replaced by palasonita and chlorite. Vesicularity is $12.25 \%$ with round to irregular vesicles scattered throughout

$$
\text { J NRM MDF inc. S } \quad \text { D } \begin{aligned}
& \text { Rock } \\
& \text { Trpe }
\end{aligned}
$$

\begin{tabular}{llllll}
$11.2,44.46 \mathrm{~cm}$ & J NRM & MDF Inc. & S & D & $\begin{array}{l}\text { Rock } \\
\text { Type }\end{array}$ \\
\hline & - & - & 4.21 & 2.32 & Basalt
\end{tabular} $112.111 \cdot 113 \mathrm{~cm} 11.3 \times 10^{-3}={ }_{-31.7}^{-4.7}= \pm=$ 


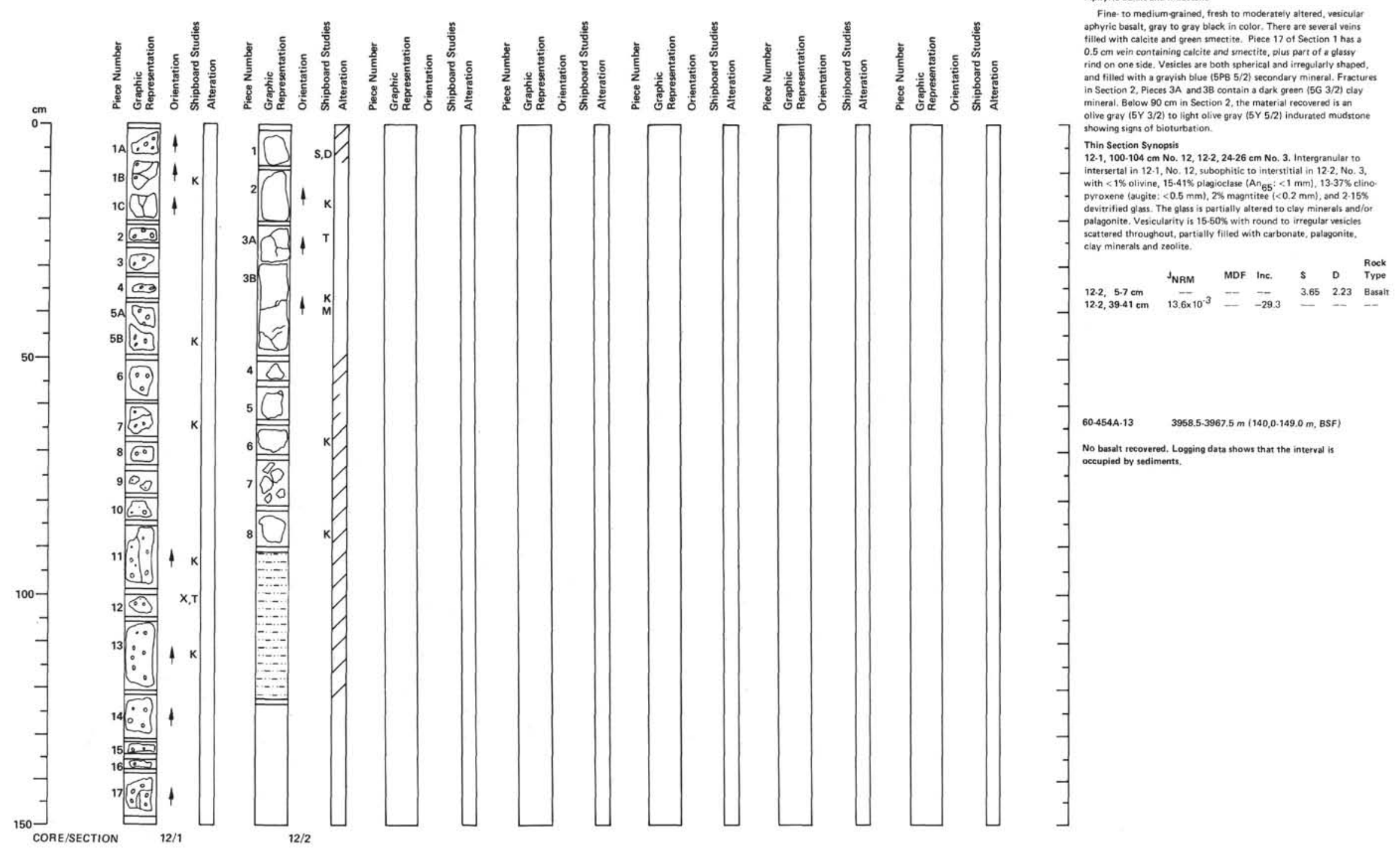

60.454A.12 3949.5-3958.5 m (131.0.140.0 m, BSF)

Aphric basalt and mudstone

, fresh to moderateiy altered, vasicuiar Cece 17 of Section 1 has (5) thowing signs of bioturbation

, (An 65 : $<1$. (1)

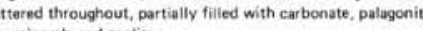

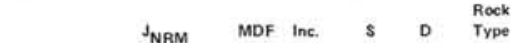




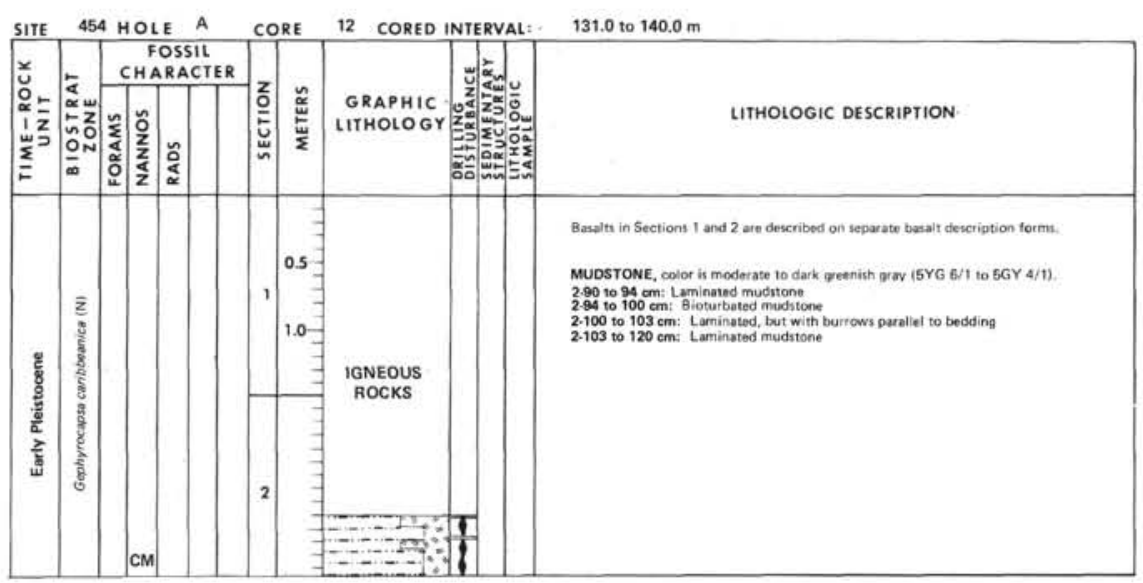

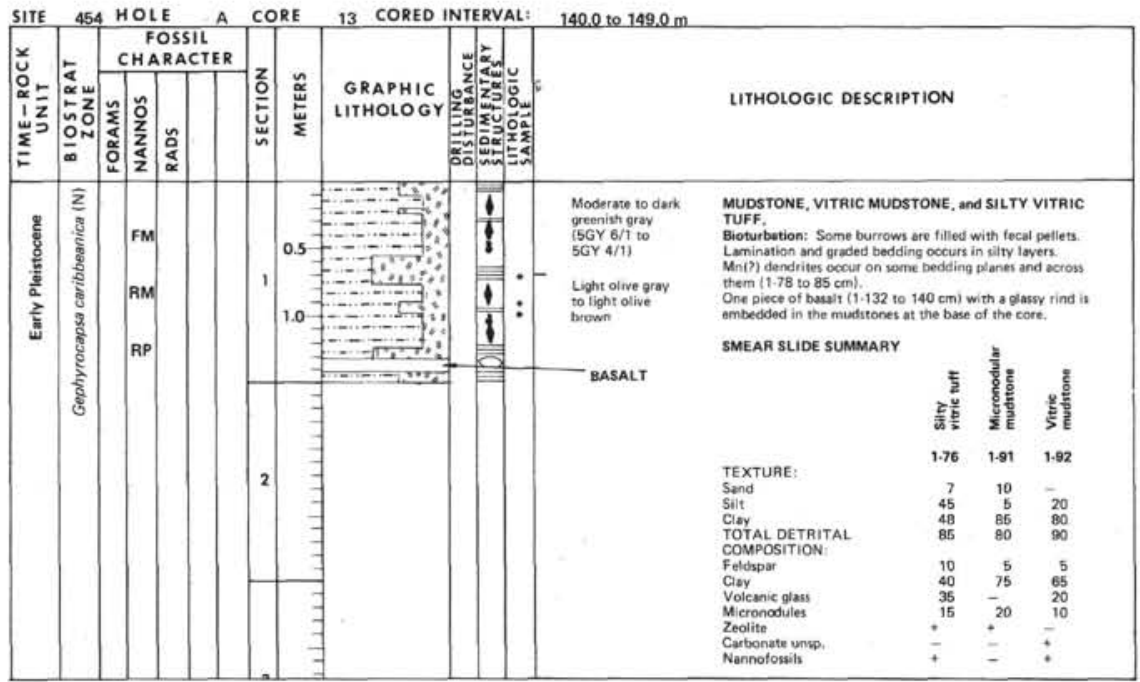




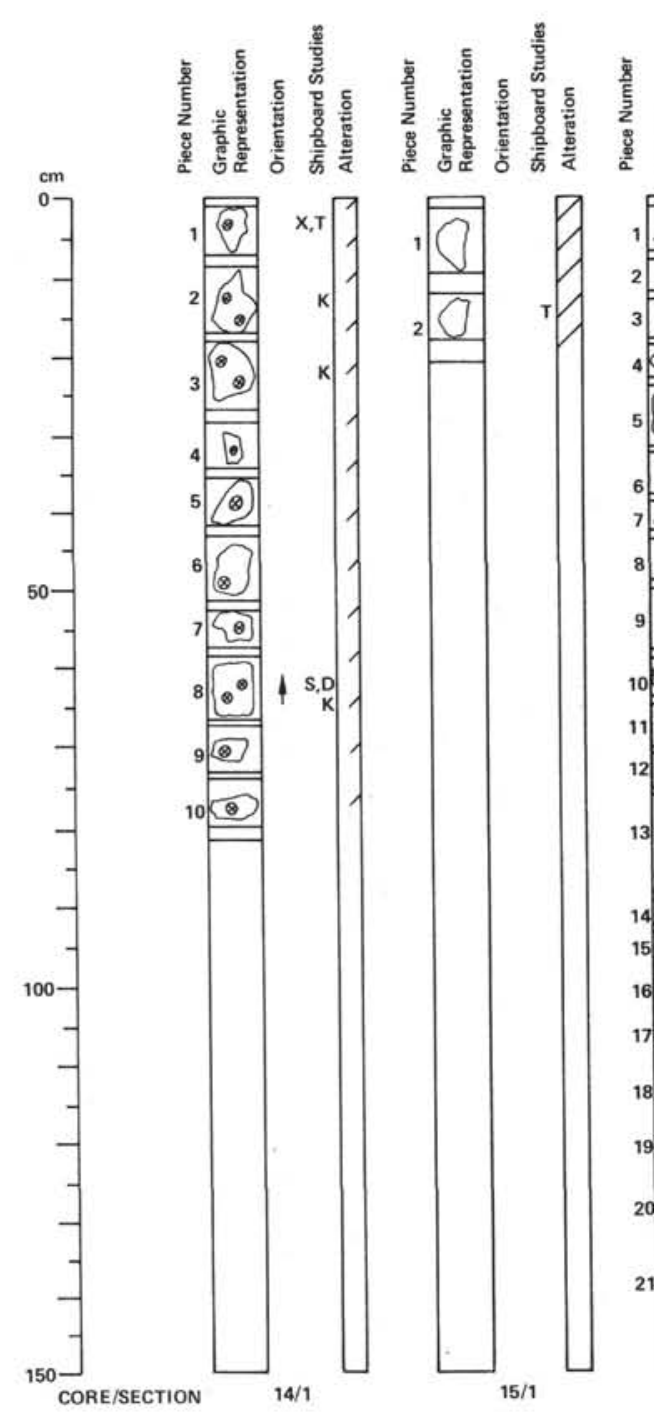

MIMH!H

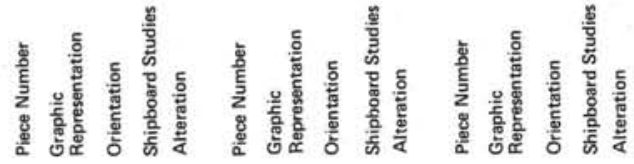

60.454A.11

$3967.5-3976.5 \mathrm{~m}$ (149.0.158.0 m, BSF)

Vesicular basalt and pillow basalt frragments, all aphyric, wern

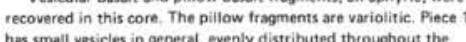

rock. Pieces 27 thow an irregular distribution of vesicles. All are silghtiv altered, Piecess 610 are pillow fragments showing vari ations in texture

Thin Section Description

basalt with intersertal groundmass containing $4 \%$ olivine $10.5 \mathrm{~mm}$

$25 \%$ plagiocisese $(0.2 .1 .0 \mathrm{~mm}), 35$ magnetite $(<.02 \mathrm{~mm})$, and $23 \%$

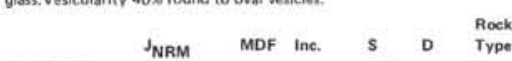

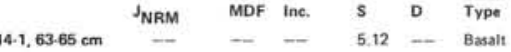

60.454A $15 \quad 3976.539880 .5 \mathrm{~m}(158.0 .162 .0 \mathrm{~m}, \mathrm{BSF})$

Aphyric basalt

Only two pieces of stightiv attered vesicular basalt, with surtaces of fragments coated with dusky vellow (5Y 6/4) clays and Fe hydroxides

Thin Section Description

icrophyric vesicular basalt with $2 \%$ brown sponet inclusions. The groundmass is intersertal and containg $2.3 \%$ oivive $(<0.2 \mathrm{~mm}), 18.20 \%$ plagioclase $(<0.5 \mathrm{~mm}), 2.3 \%$ magnet clay. Vesicularity is $50.55 \%$ with oval shaped vesicles $(0.10 .4 \mathrm{~mm})$ scattered throughout.

60.454A-16 $3980.5-3990.0 \mathrm{~m}$ (162.0.171.5 m, BSF Aphyric basat

Two types of basalt were recovered in this core. In Section 1, Pieces

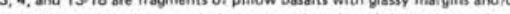

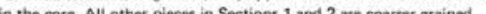
and probably represent pillow interions. They are dive gray $15 \mathrm{Y}$ 4 4 . with tresher looking patches in the interiors that are dark gray (Na).

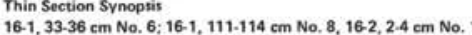

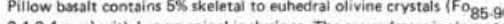
$0.10 .4 \mathrm{~mm}$ ) with and $-50.80 \%$ glass very slightly altered (11\%) to clays Vesicularity is $15 \%$ $(<0.1 \mathrm{~mm})$ with irtrogular shaped vesides concentroted in sphervili

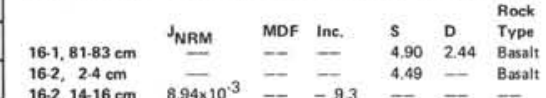

\subsection{A.17}

Aphyric basalt

Two piocess of aphyric basalt were recovered in this core from an

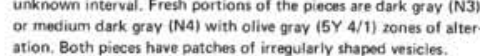




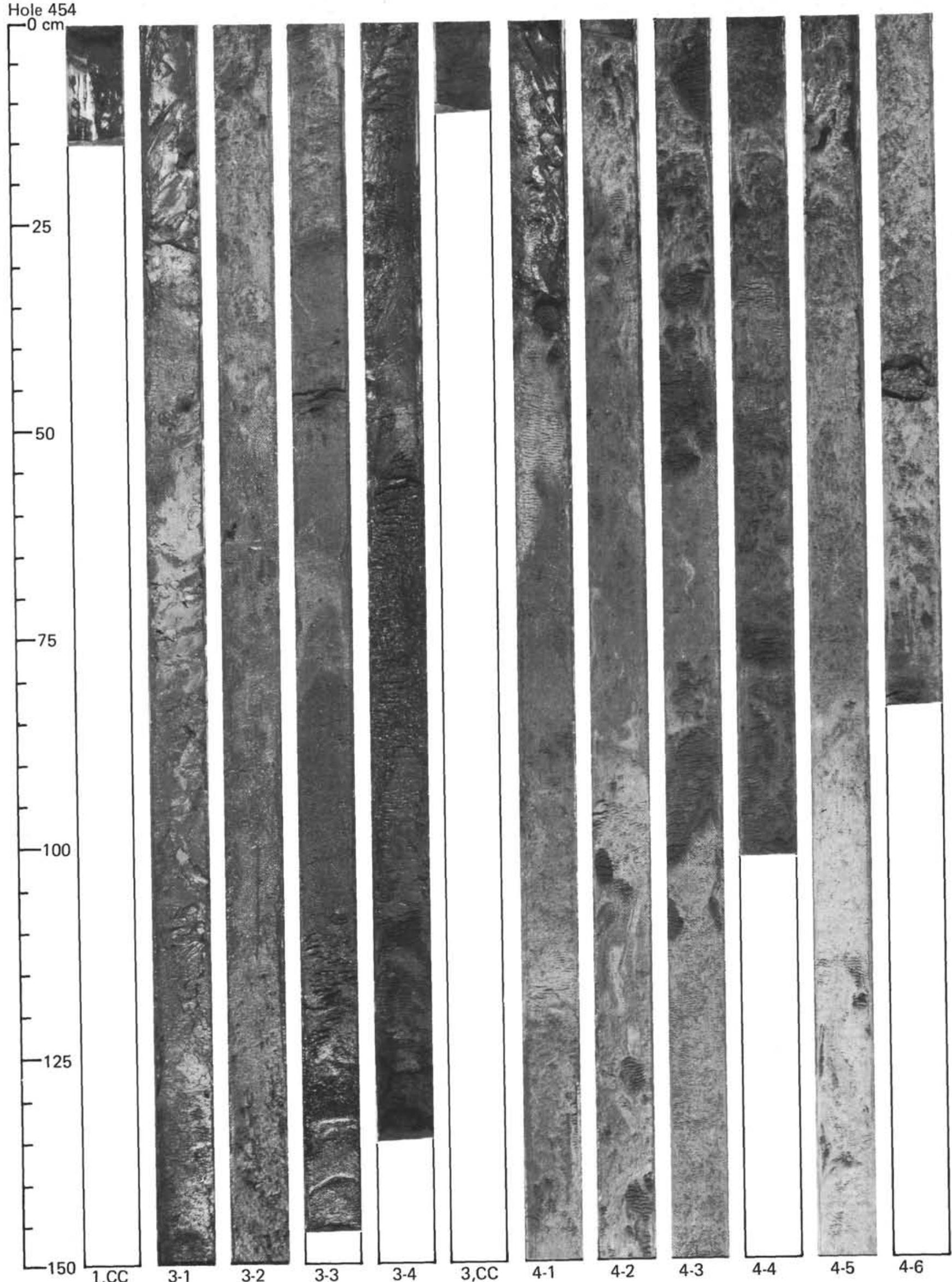




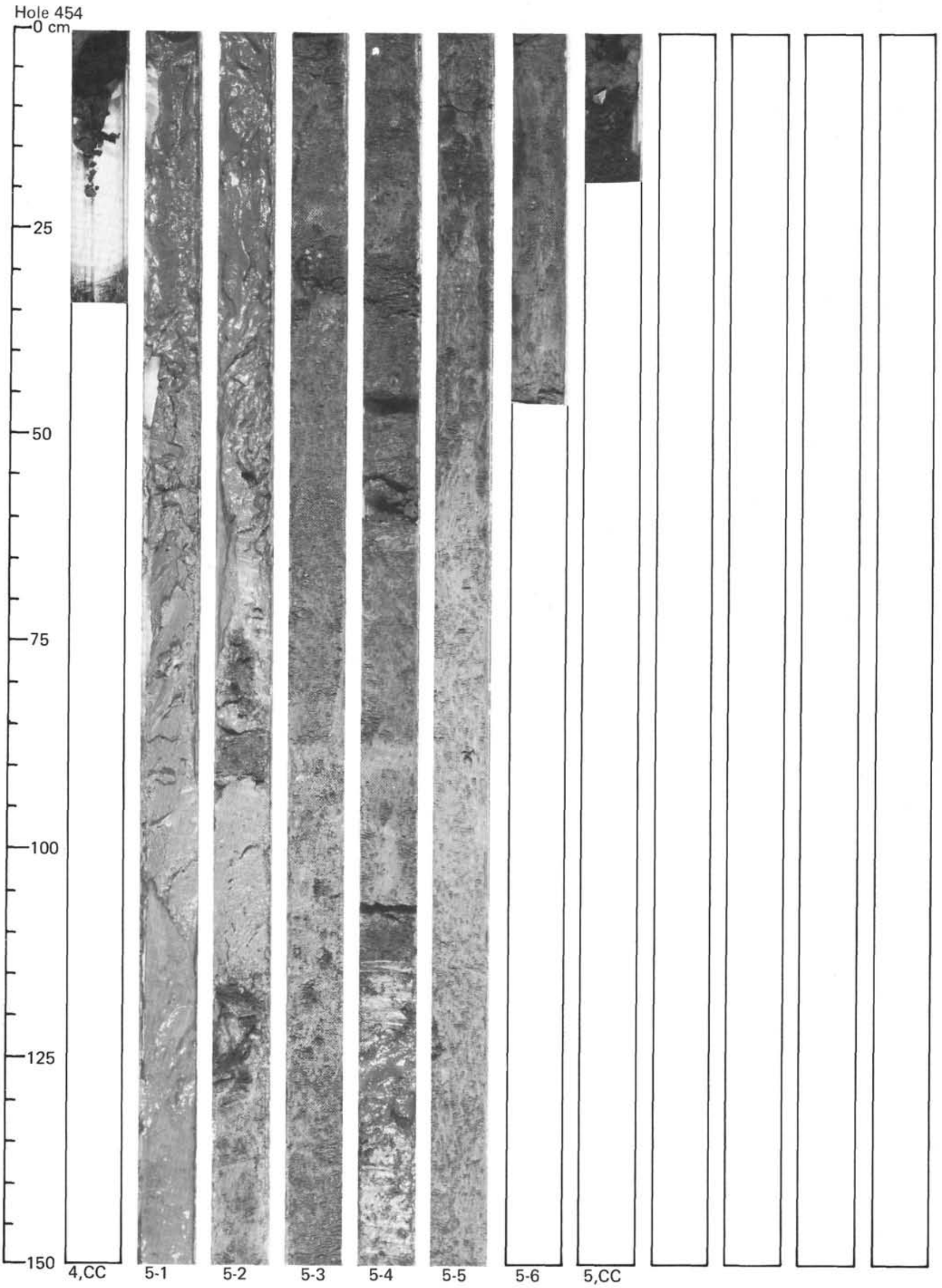


Hole 454A

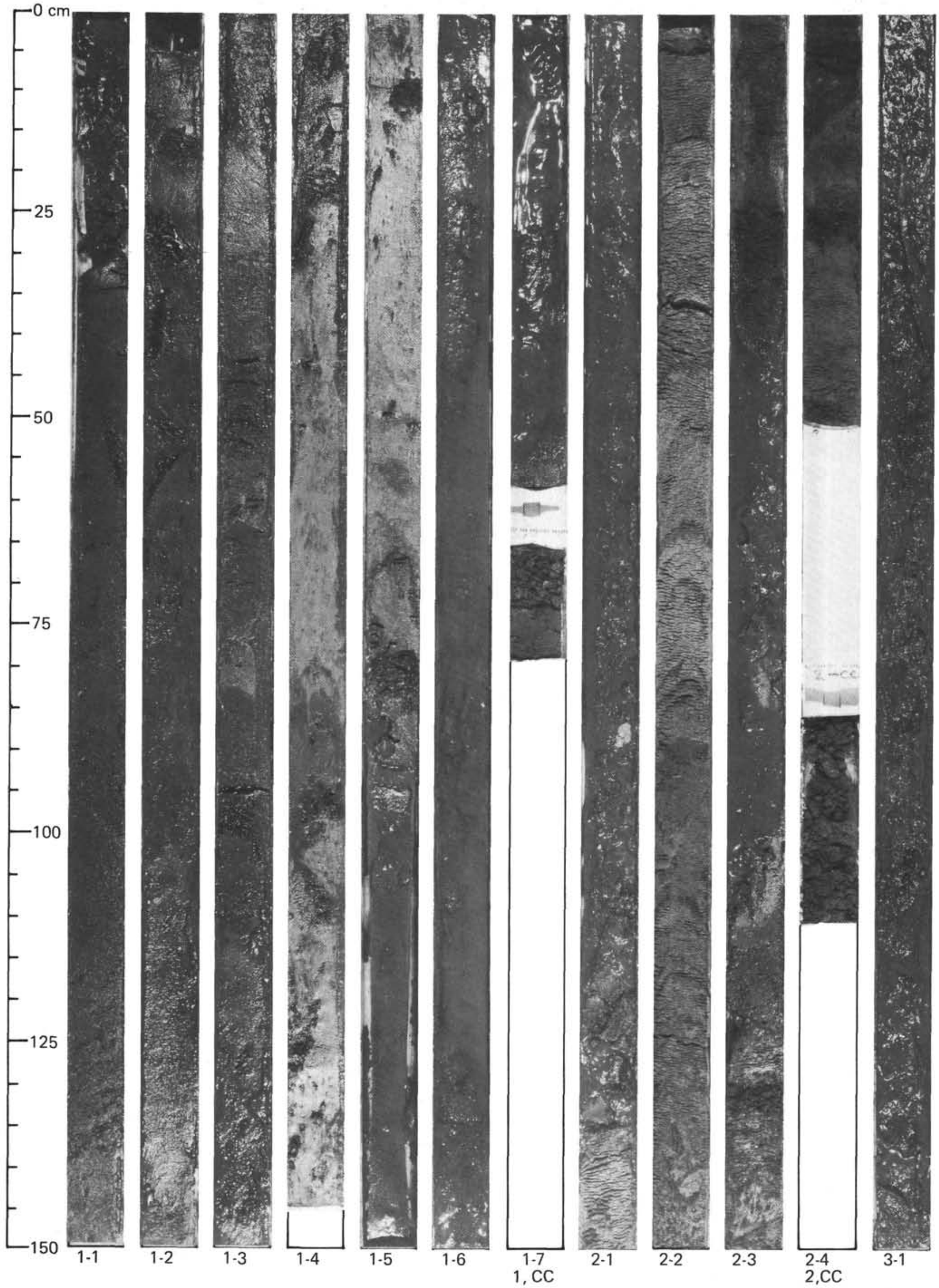




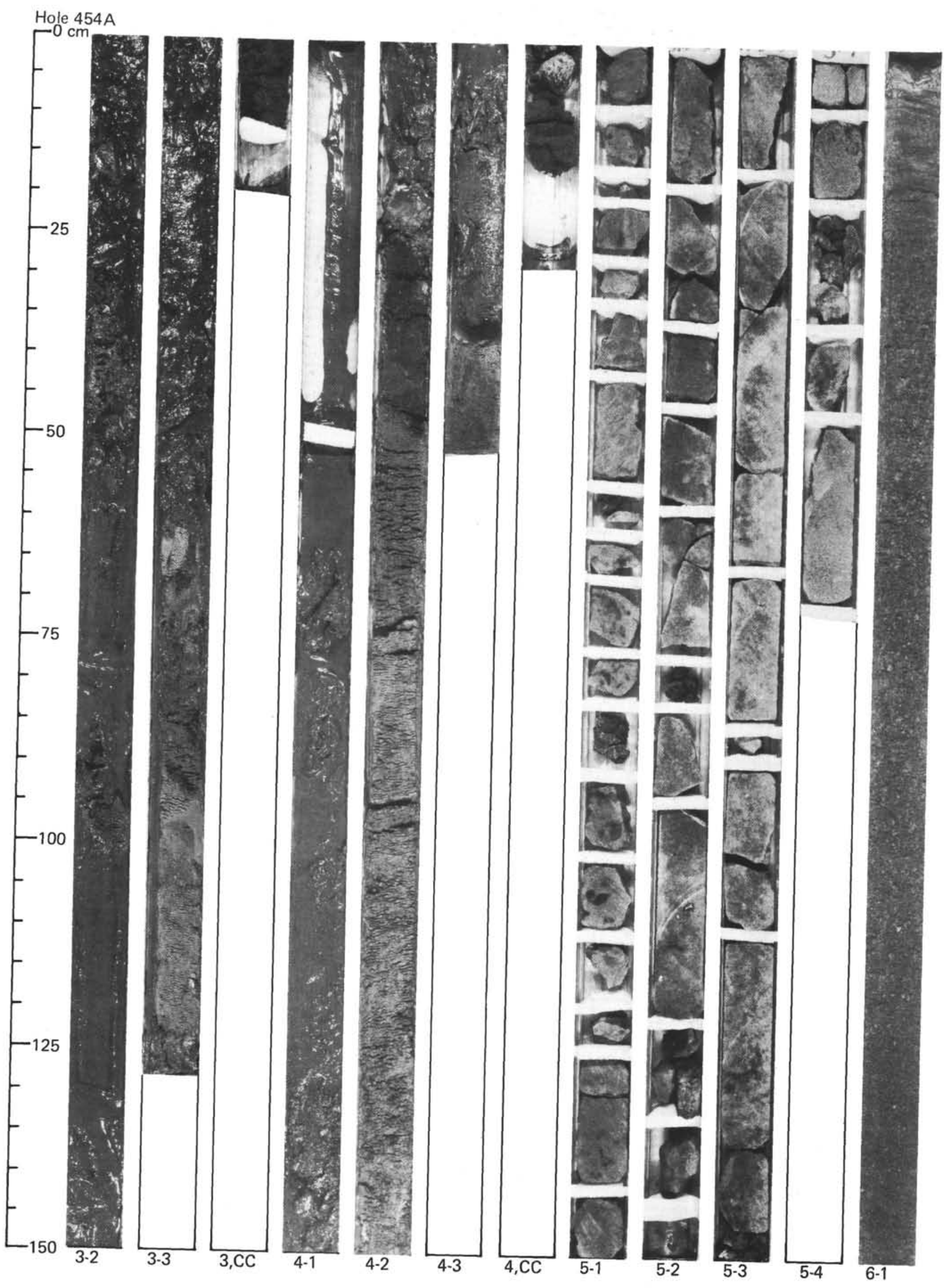


Hole 454A

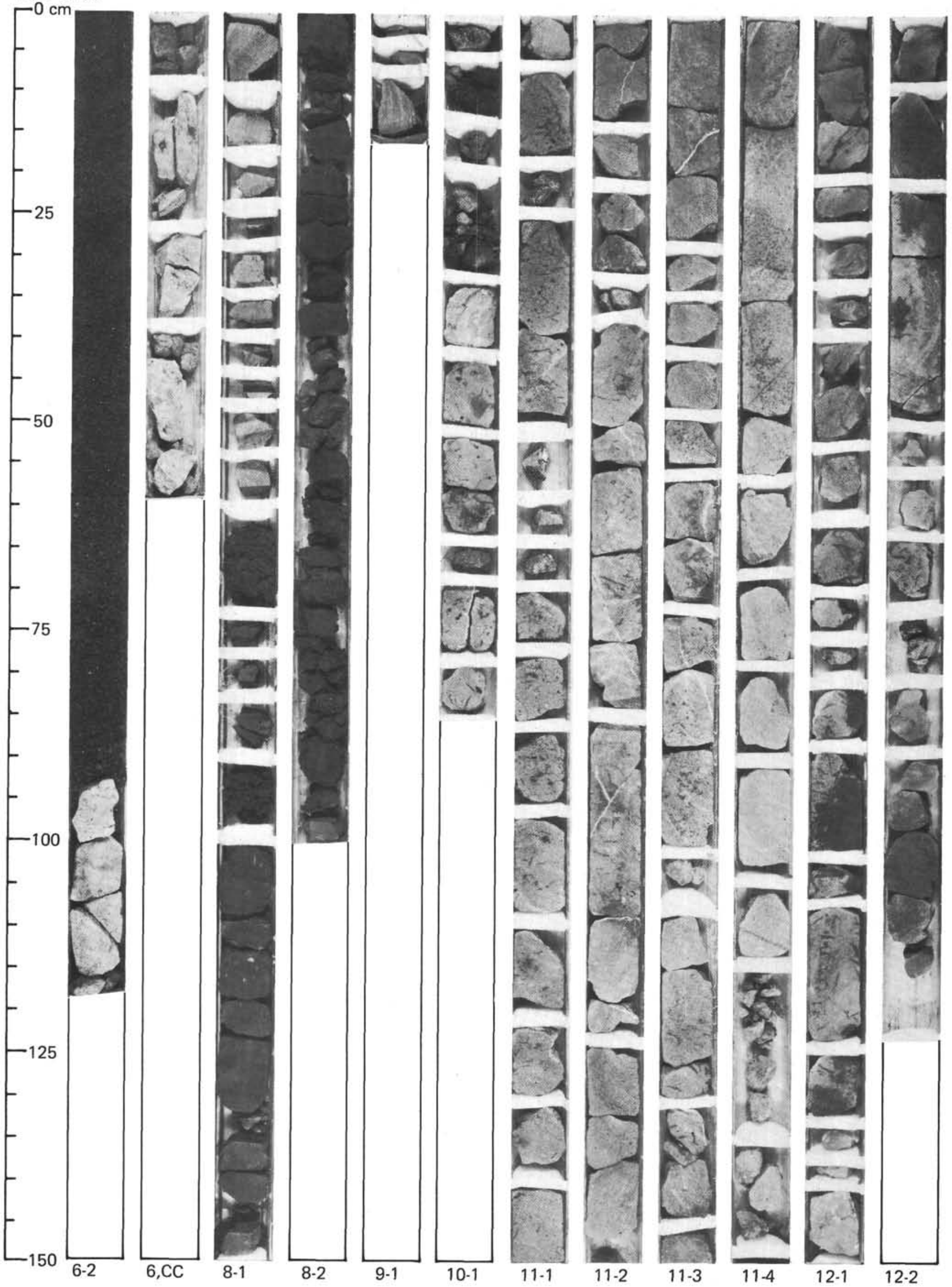


Hole 454A

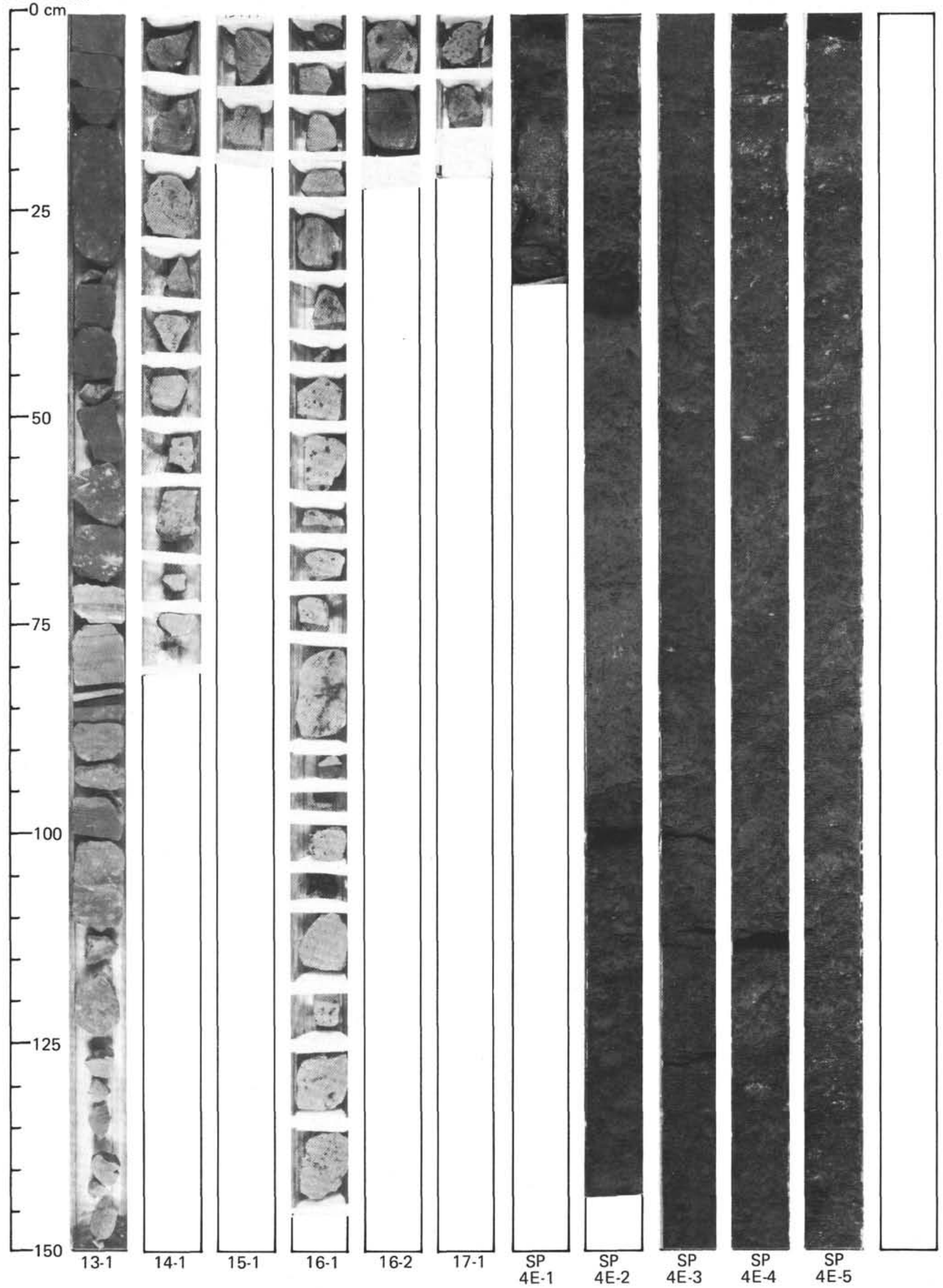

